\title{
ZOOGEOGRAPHICAL RESULTS OF THE BICENTENNIAL STUDY OF THE NORTHERN PART OF THE ASIAN POPULATION OF PHOENICOPTERUS ROSEUS
}

\author{
Boris Yu. Kassal \\ F.M. Dostoevsky Omsk State University, Russia \\ e-mail: BY.Kassal@mail.ru
}

Received: 27.07.2016

\begin{abstract}
Over a period of 205 years, there have been carried out dozens of censuses of nests and nesting bird individuals, summerings and non-nesting bird individuals, winterings and wintering bird individuals, the determinations of migration routes in the Caspian region and across the Caspian Sea, in Central and Southern Kazakhstan, Turkmenistan, Azerbaijan and Russia. Until the early XXI century, the main flamingo nesting sites were located in the Caspian region and along the Caspian Sea within the Russian Empire / USSR / Commonwealth of Independent States. It was found that such a geographical distribution of flamingo nesting sites was established until 1930 by the relative stability of the global climate conditions in northern Eurasia that have caused the stand of water level in the Caspian Sea.

During this period, in the northern part of the Asian population the monitoring of the flamingo had the form of collecting mainly qualitative information. Amongst these are the determination of the locations of breeding sites, summerings and winterings; the bird's abundance was characterised mainly using the epithets. The next period (from 1931 to 1977) was caused by the development of anthropogenic influences and by changes of global climatic conditions in northern Eurasia, which have caused a decrease in the water level in the Caspian Sea. Environmental effects of the hydrological regime changes were the most significant in the shallow northeastern part of the Caspian Sea. The breeding sites and the summerings (that were located there) had changed dislocation. Sometimes such a dislocation was observed over a wide area, up to the complete loss of breeding sites and summerings. During this period, the observations had the character of quantative information collecting and clarification of qualitative data: determination of new locations of breeding sites, duration of their existence, location of summerings and winterings, sizes of flocks and groupings, and disappearance reasons of the flamingo from former habitats. The persistent reduction of the Caspian Sea area, as well as the drying up of several sea gulfs, had caused the emergence of permanent breeding colonies on the lakes of Central Kazakhstan (Lake Shalkartenize, Lake Tengiz). The decrease in the level of continental waterbodies in Central Kazakhstan had caused an increase of their nesting and feeding properties: formed shoals became the sites of feeding and breeding of flamingos. Significant annual and long-term fluctuations of the water level in the lakes had become the reason of the periodic disappearance of flamingo colonies on certain lakes and their emergence of those on other lakes. During 1978-2015 the monitoring of flamingos in the northern part of the range of the Asian population were aimed at obtaining qualitative and quantitative indicators of nesting sites, summerings and winterings in conditions of increasing of the Caspian Sea level, the fluctuations of the water content in Central Kazakhstan, the refinement of migration dates, the spring and autumn migration routes.

The placement of the major part of flamingos on the water bodies of Central Kazakhstan by the end of the XX century has contributed to the final formation of the flight route, which had connected these habitats with areas previously populated along the Caspian Sea. In the early XXI century the permanent reproductive centre in the northern part of the Asian flamingo population remained the breeding colony on Lake Tengiz. Available data have formed the necessary information base for further quantitative and qualitative assessment of the northern part of the Asian population over three time periods caused by the state of the Caspian Sea, waterbodies of the Caspian region and Central Kazakhstan, each of which had specific characteristics that determine the placement of nesting colonies, summerings, winterings, routes of seasonal and inter-seasonal migrations in the northern part of the range of flamingos and beyond.
\end{abstract}

Key words: abundance, Asian population, breeding colony, migration route, northern part of the range, pink flamingo, summering, wintering. 


\section{Introduction}

The greater flamingo Phoenicopterus roseus (Pallas, 1811) is the most common amongst all flamingo species known at present (Anfronov et al., 2011). The breeding range of the greater flamingo is disunited (Stepanyan, 2003); its distribution is discontinuous, sporadic in tropical and subtropical regions of Europe, Africa and Asia, where this species is a sedentary, nomadic or migratory bird (Karri-Lindal, 1984). Only recently it has been found out that more than $85 \%$ of the West-Mediterranean population, distributed in the Camargue (France), Fuente de Piedra (Spain) and Molentargius (Sardinia) (Johnson et al., 1992; Cezilly \& Johnson, 1997; Bechet \& Johnson, 2008; Balkiz et al., 2010), has an established communication with the West-African population in Algeria via the Mediterranean (Samraoui et al., 2006; Touatiab \& Samraoui, 2013). There are only scattered data on permanent connections of the Asian population with other populations of the greater flamingos (Lebedeva \& Shevareva, 1971; Volkov, 1979; Karavaev \& Belousov, 1983; Andrusenko, 1986).

Despite the fact that for already the two decades five relatively isolated populations are clearly distinguished in the range of the greater flamingo (Johnson, 1997, 1998), breeding sites, wintering areas and passages of individuals from different populations (including those not related to the range of the Asian population) are presented in the descriptions in reviews and publications about rare bird species in the Russian Federation. The scientific-popular publication of AN USSR with the specific title about the greater flamingo (Kustanovich, 1986) included scattered data on the various flamingo species, about their different populations, as well as much more information about other bird species, increasing the volume of found scant data on the greater flamingo, most of which were without any bibliographic references. With an abundance of non-aggregated or not well generalised primary information based on field observations of different authors in different locations and at different times, the lack of a clear pattern of the placement and long-term change of breeding sites, summerings, winterings, traditional seasonal migration routes does not contribute to the clarity necessary in this matter. To date, some large ornithological publications (Dementiev et al., 1951; Dolgushin, 1960; Andronov et al., 2011) have mostly introductory historical significance.
They do not reflect the current state of the northern part of the Asian population of the greater flamingo considering the occurred changes and trends in its development, and necessary differentiation of data for different development periods, which are caused by changes in the Caspian Sea level and cyclical changes of the moisture of continental reservoirs in Central Kazakhstan.

The relatively large number of the greater flamingos in five isolated populations has caused that this species has the threatened status «Least Concern (IUCN 3.1 Least Concern: 106 003 769)» according to the International Red List (IUCN Red List, 2012). At the same time, a peripheral character of the major part of the range in Northern Eurasia determines the rarity of this species in this area. As a result, the greater flamingo is included in the Red Data Book of the USSR (1984), Russian Federation (2001) with the rarity category 3 (rare species, nonbreeding, migrating and regularly vagrant species), in the Red Data Books of 25 regions of the Russian Federation (Prisyazhnyuk, 2012). The greater flamingo is listed in the Red Data Books of Azerbaijan Soviet Socialist Republic (SSR) (1989), Kazakhstan SSR (1978), Turkmen SSR (1985), Republic of Kazakhstan (2010), Uzbekistan (2006), Turkmenistan (1999) and other countries where it is known. It is included in Appendix 2 of CITES (1973/1976), Appendix 2 of the Berne Convention, Appendix 2 of the Bonn Convention, the Convention on Migratory Bird Protection between Russia and India. Currently the greater flamingo is under protection everywhere in the northern part of the range of the Asian population. Places of aggregations and nesting sites of this species are usually included in Protected Areas. During the period of migration and winterings the species is protected in Russia (in the Dagestan Reserve, Agrakhan and Samursky federal sanctuaries, in Papasskoe hunting estate), in Azerbaijan (in the Akgyolsk, Shirvan and Kyzyl-Agach Reserves), in Turkmenistan (in the Khazar (Krasnovodsk) Reserve (North and Gassankuliysk sites), Sarykamysh and Ogurchinsky sanctuaries) (Ataev et al, 1978; Dzhamirzoev, 2009). However, this does not exclude cases of poaching and anxiety of birds in the colonies.

At the same time, having a variety of environmental and biological characteristics of the greater flamingo that have not assessed properly in the historical aspect, the northern part of the 
Asian population was formed relatively recently. However, to date the mechanism of its formation has not been assessed. All attempts to assess were limited to the statement of the situation that existed at the time of each local research.

The aim of this paper is to assess the results of the bicentennial study of the flamingo. The following tasks were set to the approval:

1. Establish the information base on the northern part of the Asian population of the greater flamingo in the maximum retrospective.

2. Assess the known results of censuses of breeding sites and nesting birds, summerings and non-breeding birds, wintering areas and wintering birds, assessments of the total number of individuals in the Phoenicopterus roseus population within the Russian Empire / USSR / Commonwealth of Independent States.

3. Identify the main features of the development of the northern part of the Asian population of the greater flamingo during time periods determining the placement of nesting colonies, summerings and wintering areas, and the routes of seasonal and inter-seasonal migrations in the northern part of the range and beyond.

\section{Material and Methods}

Because the material showing the process of formation and development of the northern part of the Asian flamingo population is extremely extensive, we intend to present it in the form of a series of scientific articles. The present article is the first of them. It is presented as the bibliographic review of the available information base. It includes only the ascertaining of zoogeographical results in chronological order, without any comments. The study covers a period of 205 years (from 1811 to 2015). It contains published data (in the vast majority with an indication of the primary sources) about the breeding sites and nesting birds, summerings and non-breeding birds, wintering areas and wintering birds, as well as the total number of flamingo individuals in the northern part of the Asian population.

We mean by the nesting colony the placement of mainly breeding individuals who are the participants of the reproduction process, their nests, clutches of eggs and nestlings (possibly in the presence of a certain percentage of nonbreeding individuals); the summering is the local cluster of non-breeding birds during the warm period of the year (from April to September); the wintering is the location of the individuals during the cold season (from October to March); the traditional seasonal migration routes are the routes of regular interseasonal migrations of birds from the breeding sites and/or the summering to the wintering and backwards (Kassal, 2010, 2015). The "Nesting site» is the habitat where a bird population builds nests, hatches eggs and brings up nestlings until these are able to fly. In some cases such a habitat is used as summering (as place for moulting) and wintering. Combination of nesting and summering sites is a typical phenomenon for the greater flamingo in the northern part of the range of the Asian population, but the combination of nesting and wintering sites is an exceptional phenomenon. A «Breeding population» is a population, within the range of which reproduction is observed on the nesting sites. There may be found summerings and winterings. A «Non-breeding population» is a population in the range of which there are summerings and winterings, while nesting sites are absent, and reproduction does not occur. Adults are the individuals who have reached maturity (usually since their third year of life), capable of reproduction, and having appropriate plumage coloration; subadults are the sexually immature individuals at the second year of life, yet unable to reproduction, and having the appropriate colour of plumage; young birds are the sexually immature individuals at the first year of life, yet unable to reproduction, and having the appropriate colour of the plumage.

\section{Results}

In the review study we have used in total 142 censuses in the northern part of the Asian population. These results were published in scientific literature during the whole studied period of 1811-2015 (Fig. 1).

The first reliable reference to the greater flamingo in the northern part of the range of the Asian population refers to the early XIX century: in 1810 the nesting of flamingos was found in the North-East Caspian region in the lower reaches of the river Emba (Pallas, 1811).

In the years 1831-1832 10,000 individuals were counted at the wintering on the coast of the Gulf of Hasan Kuli (Laptev et al., 1934). The spring migration was registered in April of 1832 in the Krasnovodsky Bay and in the Mikhailovsky Gulf (Karelin, 1883). Large flocks of flamingos were observed in these areas in mid-April (Zarudny, 1896). Some individuals flew from the Gulf 
Mertvyi Kultuk and Mangyshlak Peninsula to the west to the estuary of the river Ural, where they appeared late April (Karelin, 1875). Summer meetings with non-breeding flamingos in Krasnovodsk Bay were known already in the middle of the XIX century (Karelin, 1883); here, large flocks were observed late June - early July (Zarudnyi, 1896). During 1831-1875, a breeding colony of several hundred pairs of flamingos was found in the bays of Mikhailovsky and Balkhansky in the northern part of the Krasnovodsky Bay (Zarudny, 1896), where they were seen until late September - early October (Eichwald, 1837). It was found out that the breeding season of the greater flamingo lasts from late April (oviposition) to October (when the nestlings of the last brood begin to fly). Early July 1834, flamingos came together in the waterbodies defended by swamps, where they stayed together with moulting swans and other waterfowls. The northern coast of the Mertvyi Kultuk Bay was the site of a mass moulting; and from the second half of July flamingos kept together «... in such countless number that the coast seems as if covered by scarlet cloth over a large area» (Menzbir, 1918).

In the summer of 1832, flamingos were observed in large numbers on the south-east coast of the Caspian Sea in the Gulf of Hasan Kuli (Karelin, 1883). Late May - early June, small flocks were seen near the village Chikishlyar (Nikolskiy, 1886). Mid-March, a large number of migratory flamingo was observed near Lenkoran (Radde, 1885). Mid-May, a large flock of flamingos was observed in the lower reaches of the river Atrek (Radde \& Walter, 1889). Mid-June 1886, large flocks were seen near the village Chikishlyar (Zarudny, 1896). In 1832, in the north-eastern part of the Caspian Sea, flamingos were observed «... in the greatest number near the northern shores of the Mertvyi Kultuk gulf, and especially on the islands of Zhidovinnykh; here they moult» (Karelin, 1883). The existing conditions have contributed to this: the coast of the north-eastern part of the sea is formed of clay-alkali deserts, on the surface of which rainfalls accumulated; until they are dried up, flamingos use these mud areas to ensure their own protection. A lot of salt marshes are located on the Buzachi peninsula. The Mertvyi Kultuk gulf is located to the north of it. This gulf was the main place of the summer concentration of flamingos along the Caspian Sea in the XIX century. Secondary habitats were in the Gulf of Hasan Kuli and near the village Chikishlyar (Eversmann, 1866; Karelin, 1875; Severtsov, 1879; Zarudny, 1896).

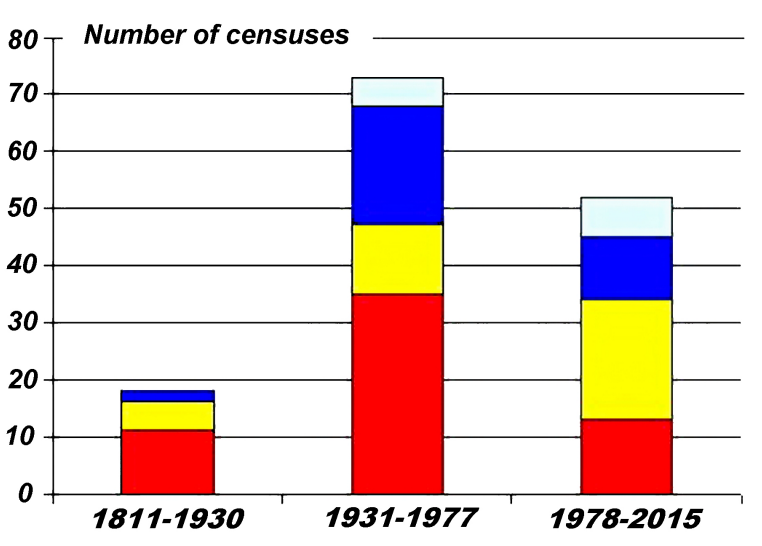

Conventions: $\square$ - total number of individuals

- number of winterings and wintering birds
$\square$ - number of summering and non-breeding birds
- number of nesting sites and nesting birds

Fig. 1. The number of censuses used for the review study of the northern part of the Asian population of the greater flamingo from 1811 to 2015 .

Autumn migration to the estuary of the river Ural was observed mid-September (Karelin, 1875); by late October flamingos flew away from the Aral-Caspian steppes (Bostanzhoglo, 1911). Migration took place at night and in the morning, in large flocks (200-300 birds per flock) (Dementyev, 1945). In mid-October, flamingos appeared at the estuary of the river Atrek. Late November and early December, the first birds were seen in the neighbourhoods of Lenkoran. Migration usually ended late December; in December flamingos were often observed in the neighbourhoods of Baku, where they stopped on the salt lakes for resting and feeding (Radde \& Walter, 1889).

In the second half of the XIX century, it was noticed that the greater flamingo «... does not nests on the Volga, but flamingos can bring out the nestlings to some lakes and coastal salt lakes of the steppes on the left side of the Volga, even at the latitude of Cherny Yar» (Yakovlev, 1873). It was related to the villages in the north of the Astrakhan province. Flamingos nested in $\mathrm{Ka}-$ myshin county in the Astrakhan province. The main reason - extensive swampy lowlands were presented there - Prishib, Moguty and Bolugty, and on Lake Shala-Kupa in Ryn-Peski named «Krasno-Gusinoe» [Red-Goose] in the XVIII and early XIX centuries (Dinesman, 1960). «... We see that around the region the flamingo is inclined not so much to the south as to the lack of concern and the bringing out nestlings» (Bostanzhoglo, 1911). In the XIX century a large colony of flamingo (at least 200 nests) was near the 
eastern shore of Lake Inderskoe (Karelin, 1875; Seebohm 1882), but it was abandoned due to excessive pursuit; apparently at the expense this colony $\ll . .$. the new nesting sites were formed at salty muds (hacks) to the east of the Baskunchak Lake»; «... The colony of flamingo inspected 21 July 1876 in the Trans-Volga steppe consisted of 410 nests. The biotope is formed by the islands in large and small salt waterbodies, inaccessible to humans due to the boggy muddy bottom» (Spagenberg, 1951). «In 1876, the collector Genke found a huge colony of 419 nests in a kyrgyz (kazakskaya) steppe among the vast hacks that represent the impassable salt marsh without vegetation between Narynsk sands and the mountain Maly Bogdo. This year, the hacks had so dried due to the water shortage that they got sometimes covered by the crust of salt. At one of these dried up areas, flamingos made their conical nests up to 2-3 meters in height from the mud mined under the crust of salt. Genke found one, two or three eggs per each depression on top of these mounds. Moreover, the nestlings had hatched from half of the eggs. It was 8 June» (Khlebnikov, 1930).

Until 1875 flamingos nested in the lower reaches of the river Ural (Karelin, 1875); their autumn migration took place along the river Ural over the North Caspian Sea late September (Poslavskiy et al., 1977). In spring throughout May, migratory flamingos were observed at the estuary of the river Ural (Dolgushin, 1960). Separate spring meetings of single birds and small groups of flamingos have been known for the lower reaches of the rivers Ilek, Trotsk, Orenburg, on the Black Sea coast and in Crimea (Sushkin, 1908). They were registered in the Urals - north of $52^{\circ} \mathrm{N}$ (Eversmann, 1885). Flamingos were observed along the river Volga till the town of Syzran and the province of Samara (Severtsov, 1879). At the turn of the XIX and XX centuries the greater flamingo «... does not only appear in the Ural estuaries, but they also bring out nestlings within the military limits. Previously, they were observed on the eastern shore of the salt lake Inderskoe, where they had nested in a colony. But now flamingos fly there only rarely since the visit by some scientists with a convoy which definitively destroyed more than two hundred nests. Now, the main residence of the greater flamingo is located on the west side of the Bukeevskaya Kirghizskaya horde...» (Menzbir, 1918).
There were data on the nesting of flamingos on Lake Sevan in Armenia (Satunin, 1907), but these were assessed as doubtful (Dementyev et al., 1951), citing the fact that the flamingos had nested just south of the border of the former USSR (Russian empire) on Lake Urmia. Data on the nesting of flamingo in Lenkoranskiy district (Buturlin, 1936) was also recognised as erroneous (Dementyev et al., 1951), but without any argumentation. However, it was recognised that flamingos were fairly frequently seen on the south-western coast of the Caspian Sea between the estuary of the rivers Kura and Lenkoran, and on salt lakes near the village Salyan (Satunin, 1907). Also some nesting sites of the greater flamingo, existing from one to several years in waterbodies of Mugan Steppe in Azerbaijan, on the south-eastern shores of the Caspian Sea, on Lake Chubar-Teniz west of the city Zhezkazgan and on Lake Kushmurun in the Kustanay region, were considered notionally and erroneously (Kustanovich, 1986).

In the XIX century, flamingos were observed in Turkestan only during migration and as casuals (Severtsov, 1879).

The appearance of flamingos in the territory of the former Semipalatinsk region was registered repeatedly over several decades. Late April 1885, one young bird was killed in the former Ust-Kamenogorsk district near the village Shulbinskoe (Selevin, 1924, 1927). During 1890-1925, in September - October the appearance of vagrant birds was observed 3-4 times (Kolmagorov, 1925). In May 1900, single birds and small flocks were observed in the lower reaches of the river Ilek (Sushkin, 1908). In October of 1902-1904 individual flocks were registered in the neighbourhood of Ust-Kamenogorsk. In April 1907, large flocks were observed near the village Berezovskoe (Sushkin, 1925). In October 1907, a separate flock was registered (Tugarinov, 1909; Ioganzen, 1911). Late September - early October 1921, one individual of a flock was killed near Ust-Kamenogorsk (Selevinia, 1927) and a scarecrow was made from this bird (Selevinia, 1924). In September 1902, five young birds were killed in Karalkovskaya duct in the Semipalatinsk district. In November - December 1905, one bird was killed in the neighborhood of Semipalatinsk. The remains of another flamingo were found (Selevin, 1927). Late October 1907 a dead bird was found in the river Semipalatinka (Ioganzen, 1911). In 
November 1907 many birds were observed near Semipalatinsk (Tugarinov, 1909). In September 1910, a dead flamingo was found in Lake Chushkaly (Selevin, 1927). In 1914, a single bird was observed on the river Irtysh near the village Shulbinskoe. In September 1914, a single bird was killed on the river Irtysh near the village Dolonskoe (Sushkin, 1914). In mid-October 1916, two of the eight birds in a flock were killed near the village Borodinskoe (Mulashka village). In mid-October 1917, an effigy was made of a dead flamingo. In April 1923, an effigy was made from a bird killed near the village Ozerki (Selevin, 1927). Early November 1912, a flock of approximately 150 juveniles was found in Pavlodar county on the Lake Yamyshevskoe. Almost all these birds were killed. (Plotnikov, 1912; Polyakov, 1915). For this period, information about the greater flamingo in Zaisanskiy and Karkaralinskiy counties is absent.

In the late XIX century, the summering of flamingos was found on the salt lake Shalkarteniz (Sushkin, 1898) where several hundred birds moulted annually. Data on the nesting of flamingos on Lake Shalkarteniz were firstly mentioned in the diaries of N.A. Severtsov (Sushkin, 1908), and also in a paper by Nasarow (1887); in 1898, nests and a large number of flamingos were found on inaccessible islands on a lake $\left(48^{\circ} \mathrm{N}\right)$ (Sushkin, 1908), with reference to Lake Shalkarteniz, as on the only nesting site of flamingos in the middle part of the kirghiz steppe. In 1899, during high-water, limnological researches of Lake Shalkarteniz were carried out (Ignatov, 1900); ornithological material was collected and subsequently processed (Bianki, 1902), but there was no flamingo, although the accompanied description indicated that they "undoubtedly inhabit» (Ignatov, 1900) - it is likely that it was not observed every year. In July 1906, a breeding colony of approximately 50 birds was found on the southern shore of Lake Tengiz, near the confluence of the river Con (Yaksha-Koni), although it was already known in 1900, that the flamingos came here during the summer period. This breeding site became the most northern $\left(50^{\circ} 18^{\prime} \mathrm{N}\right)$ amongst all known breeding sites of the flamingo (Ioganzen, 1911). Subsequently, the nesting of flamingos on the waterbodies of Central Kazakhstan was confirmed (Lavrov, 1930).

Late XIX - early XX century, the migration to the west from Lake Shalkarteniz was observed at Turan lowland along the northern escarpment of Ustyurt, in the north-eastern part and along the northern coast of the Aral Sea near the town Aralsk. Very minor migration was registered on the river Syrdarja (Sushkin, 1908; Bostanzhoglo, 1911; Spangenberg, 1951). In May 1900 single birds and small flocks of flamingos were seen in the lower reaches of the river Ilek, near the town of Troitsk and the city of Orenburg (Sushkin, 1908). In Irgiz county the great flamingo migrated on the steppe lakes (including Lake Shalkarteniz) in the summer, and early autumn they migrated to the south; the migration route of flamingos crossed the Orsk-Kazalinsk tract (Sushkin, 1908); in the early XX century, the greater flamingo was observed along Uzboy, but had disappeared by 1935 (Isakov, 1949).

After wintering on the west coast of the Caspian Sea, birds crossed the Caspian Sea. They flew to the north along the east coast and arrived at the Mertvyi Kultuk gulf and Mangyshlak peninsula, where 1 April 1904 the migration of flamingos was observed. Birds, wintering on the Turkmenian coast of the Caspian Sea, migrated along the east coast of the sea to the Mertvyi Kultuk gulf (Sushkin, 1908). Early May, they appeared on the northern shores of the Caspian Sea from the east of the Ustyurt (Bostanzhoglo, 1911). The migration route to the breeding site on Lake Shalkarteniz passed by the shores of the Aral Sea, crossing the Orsk-Kazalinsk tract between the stations Dzhelavli and Terekli (Sushkin, 1908). In some years the migration routes had displaced, capturing the northern part of the Aral Sea and the lower reaches of the river Syrdarja to the south up to the Dzhusaly station; migration of flamingos was clearly expressed near the Bolshoy Sary-Cheganak gulf: late April 1905 large flocks of flamingos were observed over there, migrating from the south, and their route was directed straight to the north (Bostanzhoglo, 1911). In spring, birds migrated annually in the lower reaches of the river Syrdarja, but in a small number; in the very late spring of 1898 the migration of flamingos in Central Kazakhstan was observed on 12-20 May (Sushkin, 1908).

In the early XX century, nesting sites in the Caucasus were found (Menzbir, 1918), as well as near the Kyzyl-Agach Bay and in Galinskie marshes at the south-eastern shore of Lake Gokchi; but already in August the flamingos left the lake (Satunin, 1907). 
In 1903, the water level of the Caspian Sea had reached a level which was the highest in the $\mathrm{XX}$ century. The area of its water surface became the largest. Nesting sites of flamingo were flooded on the coasts. This resulted in the change of the nesting sites and summering areas on the sea, which was accompanied by the migration of a part of the adult flamingos in the waterbodies of Central Kazakhstan, where the summering areas of the flamingos, insignificantly in size, were located previously under very unstable conditions, and sometimes - small breeding colonies appeared. Because the Tengiz-Kurgaldzhyn depression extends from east to west over 200 $\mathrm{km}$ and over $70-120 \mathrm{~km}$ from north to south, and it separates the Kazakh Uplands from Kokshetau upland at the junction of the steppe and semi-desert zones, its water has its own moisture regime, the alternation of wet and dry periods. Continental lakes of Central Kazakhstan subordinated to their own rhythms of changes in water availability. In this regard, their water level and area of forest reached the highest values every 9-20 years, with the relevant minima between them, which had been tracked in detail for Lake Tengiz (Voronov, 1947; Kuznetsov, 1960; Volkov, 1977a).

In accordance with this, it was found that in the early XX century breeding colonies of flamingos migrated from Lake Tengiz to Lake Shalkarteniz during the transgression of lakes in Central Kazakhstan (Sushkin, 1908); but the main breeding colonies of the northern part of the range of the Asian population of the greater flamingo were in the north-eastern part of the Caspian Sea. In the 1920s the existence of a breeding colony of flamingos in the Mertvyi Kultuk gulf was confirmed; but the flamingo was already rare to the north, in the delta of the river Volga: in July 1926 «... a flock of flamingos was seen at the southern edge of the vast hack Urdinskiy, near the natural landmark UshTagan» (Volchanetskiy, 1937). In the harsh winter of 1924-1925, flamingos migrated from the Kyzyl-Agach gulf and Hasan-Kuli gulf to the south, to Iran; significant mortality also took place (Dementyev et al., 1951).

In addition, it was stated that the greater flamingo «... nests along the northern and eastern coasts of the Caspian Sea» (Buturlin, 1936); in August 1930, a migratory flock was observed in the valley of Lake Manych-Gudilo, at the same time - on Lake Aji (Krasovsky, 1932).
The shallowing of the Caspian Sea that began in the 1930s had changed the hydrological condition of its gulfs. In some cases, it increased their nesting properties and changed the feeding properties: on the whole the level of the Caspian Sea decreased by $3.5 \mathrm{~m}$ so significantly that the area of its water surface was reduced by ca. $10 \%$. Especially the most shallow northern part had changed, where the water had receded on $40-50 \mathrm{~km}$ from the coastline: Many gulfs disappeared, including such extensive as the Mertvyi Kultuk, Kaidak, and Karakichu that dried up and were transformed into saline desert or blinders (Isakov, 1948b).

During 1934-1938 two nesting colonies were found in the southern and south-eastern parts of the Garabogazköl gulf; during the summer small migratory flocks of flamingos were observed in the gulfs of Mikhailovskiy, Balkhan and Garabogazköl (Isakov \& Vorobyev, 1940; Dementyev, 1952; Ataev et al., 1978). In 1938, one of the breeding colonies in the Garabogazköl gulf consisted of 184 nests, another of 259 nests. The information was obtained that flamingo nested on the Taraba island during at least 30 years (since 1908). But during this period, several of their colonies in the Garabogazköl gulf were destroyed irrevocably by local collectors of flamingo eggs, leaving only hardly differentiated traces (Isakov, 1948a). In 1939, the greater flamingo nested in the southern part of the Garabogazköl gulf; by the end of the 1940s, this breeding site no longer existed (Isakov, 1949); but in the early 1950 s, this breeding colony was again considered as existing (Poslavskiy et al., 1977).

At the end of the 1930s, single vagrant birds were observed at the seaside in the delta of the river Volga (Lugovoy, 1963); and in 1941, three pairs of nesting flamingos were observed on a small island in the middle of a salt lake $7 \mathrm{~km}$ north-east of the village Dzhambay on the coast of the Caspian Sea, east of the Volga river delta (Lugovoy, 1963). Until the mid-twentieth century, the greater flamingos were known from the west coast of the Caspian Sea, in the estuary of the river Volga (Dolgushin, 1960; Kazakov et al., 2004), on the waterbodies of the Samara region (Spangenberg, 1951).

The northern coast of the Mertvyi Kultuk gulf was long known as the area where flamingos grouped to moult in large numbers. However, for a long time flamingos only moulted here, but they did not nest in this area. Im- 
mature birds originally from the northern part of the Asian population were constantly observed at the Caspian Sea in summer (Isakov, 1948b, 1949; Zaletaev, 1960; Grekov, 1962; Molodovsky, 1963), and these young birds have been observed not only separately, but also in the area of breeding colonies. Probably the immature individuals of the population had accounted a large part of bird migrating over the Caspian Sea. And only a small number of them penetrated into the territory of Central Kazakhstan without forming large clusters.

The persistent decrease of the Caspian Sea level and the consequent drying up of gulfs had caused favourable conditions for nesting and massive summering areas on the north-east coast: large areas of the bottom were bared and shallow lagoons appeared (Isakov, 1948b). In 1945, a breeding colony of flamingos appeared near the shoaling coast north of the Mertvyi Kultuk gulf. It was found that «... the flamingo nests mostly on the east coast of the Caspian Sea in the gulfs Kaydak and Komsomolets» (Dementyev et al., 1951). In 1946, a colony of 50 to 500 nests and young flamingos were observed on two sites on the mud shallows in more than $500 \mathrm{~m}$ from the water in the Kaydak gulf and the Mertvyi Kultuk gulf. However, already in 1947 the gulfs dried up. And these nesting sites disappeared. Then breeding colonies were displaced to the throat of the Kaydak gulf, opposite the Cape Kzylkair and on the entrance into the Mertvyi Kultuk gulf between the Prorva island and the Buzachi peninsula. Adults, their nests and young birds were observed there (Chernoskutov \& Badamishin, 1948). There, flamingos found food in prosperity, and the impassable marshy coast guarded their nests from ground predators. The total number of nests in four colonies was about one thousand (Isakov, 1948a). Since 1947, flocks of non-breeding birds were observed in summer ibid, on the north-eastern coast of the Caspian Sea (Molodovsky, 1963; Gistsov, 2004). The total number of flamingos in the warmer months, within the (former) Soviet Union was assessed at ca. 50,000 individuals (Dementyev et al., 1951).

The sea coast and the North Caspian region were not only the final site for nesting and summering of flamingos in the Caspian Sea and Central Kazakhstan, but also the transit point on the spring and autumn migration routes, extending to the wintering areas on the Caspian Sea and beyond.
The degree of flamingo conservatism is extremely high in relation to the chosen places of wintering and nesting (Isakov, 1948a; Spangenberg, 1951; Grekov, 1962). Therefore, till 1945 the wintering sites along the Caspian Sea and on Lake Urmia in northern Iran (Dementyev et al., 1951) and their state remained relatively stable; occupancy by wintering birds has varied slightly and it was determined only by weather and climatic conditions per year. In the early twentieth century, flamingos spent winter time at the estuary of the Balkhan gulf near the island Dag-ada and near the railway station Coylyu, but by mid-century the wintering area disappeared due to the shallowing of the sea (Dementyev et al., 1951). A change in environmental conditions stimulated the birds to fly away in search of suitable sites. Being ringed in the Kyzyl-Agach Reserve on 18 February 1948, a bird was caught in September 1948 in the estuary of the river Kura. Another bird, being ringed on 25 March 1937 in the Hasan-Kuli gulf, was caught at the same place on 14 February 1939 (Dementyev, 1945). Casual encounters of flamingos were known in Transcaucasia and in the North Caucasus: to Novorossiysk, Krasnodar, Dzaudzhikau, in Dagestan, Abkhazia, on Lake Sevan, in Dzhankoy on the Crimean peninsula (Dementyev et al., 1951).

In 1933-1934 about 20,000 birds spent the winter in the Kyzyl-Agach gulf on the Turkmenian coast in the south-eastern part of the Caspian Sea (Tugarinov \& Kozlova-Pushkareva, 1938). In the winter of 1937-1938, 20,000 birds were also accounted in the Hasan Kuli gulf between the village Chikishlyar and the Iranian border. Also, 150 individuals were observed in the Krasnovodskiy gulf (Isakov \& Vorobyev, 1940). Although their number was usually about 10,000 birds in these places (Laptev et al., 1934). The sea coast near the Hasan-Kuli gulf and the settlement of Chikishlyar was the place of permanent residence for non-nesting birds. In 1940, large flocks of flamingos were observed there during the summering (Dementyev, 1952). In March 1942, 6000-8000 birds were accounted at the same place (Dementyev, 1945). At that time some individuals were already able to migrate from wintering areas to breeding sites and summerings. One of the main winterings of flamingos in the northern part of the Asian population continued to exist on this seacoast: in the severe winter of 1944/1945, 
flamingos migrated from the Kyzyl-Agach gulf and Hasan-Kuli gulf to the south, to Iran; significant mortality was observed (Dementyev et al., 1951). In 1946-1947, 6000-8000 birds were accounted in the wintering in the Hasan-Kuli gulf (Dementyev, 1952). In the 1947-1948, 15,00020,000 birds were at winterings on the coast of the south-eastern part of the Caspian Sea (Lebedeva \& Shevareva, 1970). Ibid, in 1948-1949 and 1949-1950, the number of individuals during the wintering was reduced from 15,000 to 200-300 birds due to the very severe winters (Grekov, 1962). And by spring, the number of birds decreased even to 25-30 individuals (Poslavskiy et al., 1977). This reduction in the number of individuals was not only caused by the death of birds. It also was a result of migration of a part of those further southwards. Ibid, in 1950-1951, 6000-16,000 birds spent the winter there (Dementyev, 1952). According to another assessment, this number was 11,000-13,000 individuals. In 1951-1952, it was 12,300 individuals. In 1952-1953, it was 8000 individuals. In 1953-1954, this mumber was 2000 individuals. In 1958-1959, it was 2000 individuals. And finally 16,000 individuals were registered in the Krasnovodskiy gulf (Poslavskiy et al., 1977). The number of birds that spent the winter on the Iranian coast of the Caspian Sea had remained unknown (Demetyev et al., 1951).

The steady reduction in area of the Caspian Sea, drying up of a number of gulfs and the loss of nesting sites contributed to the emergence of permanent breeding colonies on the lakes of Central Kazakhstan: Shalkartenize, Tengiz, etc. As a consequence, breeding colonies of flamingos were gradually forced to leave the sea coasts. A decrease in the level of continental waterbodies in Central Kazakhstan caused the same effect, an increase in their nesting and feeding properties: formed shoals became the feeding habitats and places for the conical mud nests of the greater flamingos. Water remained on the main shallow of Lake Tengiz (in Bolshoy Tengiz), even in 1940, the driest and lowest water year. Significant annual and long-term fluctuations of the water level inherent in semiarid waterbodies, affected the presence or absence of suitable nest sites, and, also, the concentration of salts. This, on its turn, influenced the composition and quantity of aquatic organisms that are food objects for the greater flamingo (Isakov, 1948a; Cheltsov-Bebutov, 1958; Dolgushin,
1960; Volkov, 1977a). All this was the reason for a periodic extinction of flamingo colonies on some lakes and the emergence of birds on other lakes, having a more suitable hydrological regime (Cheltsov-Bebutov, 1958; Chekmenev, 1964; Volkov, 1977a). In the winter of 1945, flamingo nests were found on one of the islands on Lake Tengiz (Isakov, 1948b); ibid, late autumn 1947, old nests were found again (Vladimirskaya \& Mezhenny, 1952).

The placement of most of the flamingos at the waterbodies of Central Kazakhstan contributed to the final formation of the migration route, that connected these habitats and areas along the Caspian Sea that were inhabited previously. Nomadic birds were observed occasionally in the steppes between the northern coast of the Aral Sea and Mugodzhary in the summer period. Rare casual encounters with flamingos in the lower reaches of the river Syrdarja, in the eastern part of the Kyzyl-Kum desert, in the Merv oasis in the lower reaches of the river Tedjen were known (Spangenberg, 1951). Moreover, the resettlement of flamingos further to the east had already begun at that time, first by single individuals during the summer migrations: late August 1967, a single bird was observed in the natural landmark Gorkiy Klyuch on the western shore of Lake Alakol (Auezov \& Grachev, 1977). Moreover, it was noted (Dementyev et al., 1951) that many authors (without references) mentioned the greater flamingos from the north-eastern parts of Kazakhstan. Due to the formation of migration routes in Kazakhstan, active migration of birds in the area of the northern coast of the Aral Sea was often observed (Spangenberg, 1951; Dolgushin, 1960) and along the northern escarpment of Ustyurt (Varshavskiy et al., 1977). During 1950-1960, migrating flocks of flamingos (from 160 to 770 birds per year) were registered regularly near the town of Aralsk. These flocks flew mainly to the northeast during spring migration. Permanent migration along this route had proved the assumption on the flamingo's nesting in the former Adzhibeyskiy gulf of the Aral Sea (Kostin, 1956).

A progressive decrease in the level of the Caspian Sea had continued to influence the placement of flamingos in the region. During 1950 1953, a colony, consisting of about 500 pairs was located in the Mertvyi Kultuk gulf and Kaydak gulf (Neruchev \& Khudyakov, 1967); at the end of the 1950s, approximately 1000 pairs of fla- 
mingo nested here (Dolgushin, 1960). Data on the nesting of flamingos on the north-east coast of the Caspian Sea from the estuary of the river Emba to the Buzachi peninsula also appeared periodically (Isakov, 1948b; Spangenberg, 1951; Dolgushin, 1960; Neruchev \& Khudyakov, 1967; Poslavskiy et al., 1977); nomadic birds were occasionally seen along the river Emba without dates (Dementyev et al., 1951).

In 1952, remnants of flamingo nests were found on Lake Akh-Chala in the Mugan Steppe of Azerbaijan on small elongated islets, but later this lake went dry (Patrikeev, 2004); three colonies were found in the Kyzyl-Agach Reserve; however, the flamingos ceased to nest here already the next year (1953). Early October 1952, one bird was killed on Lake Zaisan (Dolgushin, 1960). At the same time, Lake Beybitkul was indicated as a nesting site of the greater flamingo (Sludskiy, 1959). But by the mid-1960s, nesting sites were not found here (Neruchev \& Khudyakov, 1967). In the summer time, meetings of flamingos on the east coast near the Garabogazköl gulf were common, and the birds were observed in smaller numbers in the Krasnovodskiy gulf (Poslavskiy et al., 1977). During 1954-1956 and in later years, significant colonies were located in Severny Cheleken in the Krasnovodsk Reserve (Zaletaev, 1960).

Impermanence in the existence of breeding colonies and places of summerings in different parts of the northern part of the range of the Asian population caused a change in the time of migration and winterings (both permanent and transit). On 29 November 1951, the first migratory flock (of 300 birds) was observed in the Hasan-Kuli gulf; the abundance of flamingos increased in the second half of the month. On 6 September 1952, the first flamingo was seen near the village Chikishlyar. On 15-16 September the displacement of the route of mass migration aside Iran was noted due to deteriorating weather; the migration route was restored due to the warming up at the end of the month. In 1953, the autumn migration here began mid-October (Poslavskiy et al., 1977). At the same time flamingos from Central Kazakhstan, the Northern Caspian Region, the northern coast of the Caspian Sea not only came together on the southern coast of the Caspian Sea, but a mass migration of those flamingos, who wintered outside of the northern part of the range of the Asian population, passed through these winterings.
During the 1950 s, the conditions of wintering changed radically in the south-eastern part of the Caspian Sea: spillages of the river Atrek completely disappeared, the Hasan-Kuli gulf dried up, shallow-water coastal lagoons became shallower (Poslavskiy et al., 1977). Most of the remaining flamingos, spending winter time in the Kyzyl-Agach Reserve, had died in the most severe winters. In 1950 the number of wintering birds was declined from 15,000 to $200-300$ individuals. It was a result of the decrease of winter temperatures in these areas down to $-20^{\circ} \mathrm{C}$, and the snow depth was up to $60-80 \mathrm{~cm}$. During the winters of 1953-1956, flamingo-underyearlings in gray plumage were not numerous in the Kyzyl-Agach Reserve. They were totally absent on the south-east coast of the Caspian Sea, up to the Hasan-Kuli gulf (Grekov, 1962). During another severe winter, 1956-1957, in the Kyzyl-Agach, the number of individuals decreased from 5000 to 300-400 extremely emaciated birds (Grekov, 1962). In 1958, the total number of flamingos in the northern part of the range of the Asian population was 50,000 individuals (Dolgushin, 1960); in 1958-1959, approximately 3000 birds (mostly adults) wintered in the Kyzyl-Agach (Lebedeva \& Shevareva, 1970); apparently the others birds flew away for the winter outside the northern part of the range of the Asian population. During this period, it was found that wintering sites of the same individuals are constant; but the birds could change the location of wintering sites due to sharp changes in environmental conditions or under the influence of disturbance. Birds, ringed at Caspian winterings, were found either on the sites of labelling, or in the immediate neighbourhood of these places. This is evidence of the formation of a fragment of the population that is located mostly not beyond the limits of the northern part of the range of the Asian population. Extremely severe winters adversely affected the number of flamingos on the southern coast of the Caspian Sea; these occurred periodically (every 5-8 years) (Grekov, 1962; Krivonosov et al., 1978). That is why the migration of flamingos to the south was observed in severe winters, despite the affection of birds to the wintering sites (Volkov, 1977b, 1979); nevertheless some birds remained on the wintering sites; some of these (sometimes a significant number) died (Dyunin, 1960; Grekov, 1962). By the 1960s, the number of wintering birds on the Caspian Sea had decreased by 10 
times compared to 1930-1940 (Orlov, 1967).

The migration of flocks after wintering to the north lasted from late February - early March to April; a mass migration took place gradually, in the second half of March and early April. In 1951, the spring migration from wintering areas to the Kyzyl-Agach gulf, and from the sea coast near the Hasan-Kuli gulf to the nesting sites begun in the first half of March (Tugarinov \& Kozlova-Pushkareva, 1935); small groups of flamingos stayed during the summer on the wintering sites after the majority of wintering birds had flown away. Mid-February 1952, flocks preparing for migration were observed over there; On 21 February, about 400 birds in seven flocks migrated to the north; in mid-March, the migration had increased; on some days, 4-5 flocks (2400-3000 birds in each) were observed; in April, the abundance of flamingos was low $-1-7$ flocks $(5-15$ birds each) per day migrated (Dementyev, 1952; Lebedeva \& Shevareva, 1970). In mid-May 1952, five birds were seen in the Hasan-Kuli gulf; on 6 June 1953, 47 individuals were observed (Poslavskiy et al., 1977). Late February 1953, the first flocks (60-100 birds each) migrated along the existing migration route along the eastern coast of the Caspian Sea from the wintering sites to the breeding sites and summerings; a mass migration was registered in March; the last flocks were observed on 13 May (Poslavskiy et al., 1977). In March the first migratory flamingos appeared south of Mangyshlak. The greatest number of migrating flamingos per day was observed here om $10 \mathrm{~s}-20 \mathrm{~s}$ days April to late May (Molodovsky, 1963). The mass migration from the Krasnovodskiy gulf through the desert of the Krasnovodsk plateau to the north began in April, while on the north-east coast of the Caspian Sea the migration was observed early April (Poslavskiy et al., 1977).

During the summer period, in the postbreeding period and during autumn migration in the late 1950s, 6 single birds were observed, as well as two groups containing respectively 3 and 4 birds in the delta of the river Volga ( $\mathrm{Ru}-$ sanov \& Krivonosov, 1988).

Reliable data that breeding colonies of flamingos on Lake Shalkarteniz and on Lake Tengiz had not disappeared, were obtained only in the mid-twentieth century; the greater flamingo nested on sandy islands on Lake Shalkarteniz (Volkov, 1977a), but only in those years when the water depth in the lake did not exceed 3 $\mathrm{m}$ (Andrusenko \& Zhuliy, 1977). In 1953, 15,000 nests of flamingos were accounted on Lake Tengiz (Chekmenev, 1962). In addition, in June 1954, a breeding colony containing about 400-500 flamingos (including non-flying young birds) was found on Lake Ashchitastysor (Sludskiy, 1960; Dolgushin, 1960). However, in 1957, this lake was dried up (Cheltsov-Bebutov, 1958), and in subsequent years it was not mentioned as a location of a flamingo colony: in 1969-1975, this lake remained dry (Volkov, 1977a). In 1955-1957, flamingos continued to nest on Lake Shalkarteniz and on Lake Zhaman-Akkol (the abundance of this new colony was more than 1500 pairs), and in 1956, several birds with brood-patches were caught in this colony (Cheltsov-Bebutov, 1958). But from time to time the lake had also been exposed to a complete drying up (Spangenberg, 1951; Dolgushin, 1960; Volkov, 1972; Danilenko et al., 1977), so that the nesting colony occasionally alternated with summerings or the flamingos completely disappeared from the lake. With the shortage of feed in places of permanent placement, flamingos daily flew long distances (3040 or even $50-60 \mathrm{~km}$ ) to waterbodies with a greater abundance of food (Syroechkovskiy \& Rogacheva, 1975). In 1958, the breeding colony was re-found on Lake Tengiz (Dolgushin, 1960; Chekmenev, 1962). The islands and shoals on Lake Tengiz periodically disappeared due to the water level and the destructive effect of ice movements, and then they appeared again. Sandbar islands annually changed their shape and size; according to that, locations of the breeding sites and summerings of flamingos changed within this vast waterbody. Until 1958, flamingos nested periodically in the closed lakes of Tengiz, Shalkarteniz, Jaman-Akkol, Ashchitastysor in Central Kazakhstan, as well as on the north-eastern coast of the Caspian Sea on the blinder Mertvyi Kultuk and in the Komsomolets gulf (Spangenberg, 1951; Red Data Book of the Kasakh SSR, 1978; Andrusenko, 1980, 2007; Lankin, 1981; Stotskaya \& Krivenko, 1988; Krivenko, 1991; Khrokov, 1991).

In the late 1950s, the whole northern part of the Asian population of flamingos was estimated at 30,000-50,000 individuals (Red Data Book of the Altay Krai, 2006; Nazarenko \& Bessonov, 2009); the vast majority of breeding birds were on Lake Tengiz. Ibid, a large number of molting 
individuals was also observed; they did not participate in reproduction (Dolgushin, 1960). In 1958-1959, researchers of the Institute of Zoology of the Academy of Sciences of the Kazakh SSR investigated for the first time the breeding colony of flamingos on the small low-lying island Rysakov on Lake Tengiz. In 1958, 50,000 adult birds were counted here (Volkov, 1977a) and about 24,000 nests; of these, at survey time at most 8000 nests were registered with eggs. In addition to this breeding colony, by the nature of food migrations of flamingo it was found that another small breeding colony was located in the north-western part of Lake Tengiz. It was located somewhat north of the island Luna (Dolgushin, 1960). In May 1959, a lump oviposition of $16,000-18,000$ birds was observed $(27 \%$ of all nesting birds of all species on this lake) (Gavrin, 1968), where nests of the previous year were not found (Chekmenev, 1962, 1964); but the breeding colony had disintegrated at the beginning of the breeding period as a result of human intervention; and during several years, flamingos did not nest on Lake Tengiz.

In the period of 1959-1969, a sharp decline in the number of flamingos occurred due to the general draining of the territory of Central Kazakhstan. The reason was that the workers of the Tselinograd fish factory acting on the lakes of the Kurgaldzhinskiy Reserve, had built several dams on ducts in the rivers Nura and $\mathrm{Ku}$ lanutpes. And these dams somewhat lifted the level of Lake Kurgaldzhin, but it led to a gradual drying of Lake Tengiz and other lakes. A total of 60 dams without water outlets and spillways were built in the river Turgay (Lebedeva \& Shevareva, 1970). In 1968 and 1969, Lake Baytak, Lake Renkul and Lake Zharkul (relatively large lakes in the lower reaches of the river Turgay) almost completely dried out. Floods of the rivers Turgay and Irgiz no longer reached Lake Shalkarteniz, which transformed into a vast salt marsh and it lost its importance for waterfowls (Lebedeva \& Shevareva, 1970). As a result, Lake Tengiz remained the only waterbody in the northern part of the range of the Asian population, where the nesting flamingos were observed regularly (Elkin, 1969; Volkov, 1972, 1975, 1977; Andrusenko \& Zhuliy, 1977; Andrusenko, 1979, 2007; Stotskaya \& Krivenko, 1988; Koshkin, 2004). However, the placement of the breeding colonies of flamingos on Lake Tengiz changed due to changes in the water level: in
1962 and 1965, their nests and nestlings were found in the estuary of the river Kulanutpes. In 1965, by request of the Moscow zoological centre, employees of the Kurgaldzhinskiy hunting reserve caught 87 birds, most of which moulted at shallow waters in the south-eastern gulf. In addition, up to 300 non-flying nestlings were observed on saline muds in the north-western part of Lake Tengiz, slightly to the north of the island Luna (Lebedeva \& Shevareva, 1970).

Anthropogenic changes in the hydrological regime of waterbodies of Central Kazakhstan caused that the abundance of the northern part of the Asian population of flamingos was undermined irrevocably. While in the mid-1950s, at least 50,000 breeding birds were known on Lake Tengiz (Dolgushin, 1960), at the end of the $1960 \mathrm{~s}$, the number of adult flamingos in Central Kazakhstan was not more than 14,000 15,000 individuals, even taking into account the possible omissions during aerial counts (Lebedeva \& Shevareva, 1970).

For the first time an absolute census of the number of flamingos on the lakes of Central Kazakhstan was carried out in 1966 (Elkin, 1969). At the same time aerial photography was used, which allowed obtaining data of censuses close to valid. By decryption of photographs of flocks and clusters, the total number of flamingos on the lakes of Central Kazakhstan was identified as approximately 12,500 individuals. This value was repeatedly mentioned in publications of several authors (Lebedeva \& Shevareva, 1970; Elkin et al., 1975; Volkov, 1977a). The vast majority of individuals, both nesting and summering, was on Lake Shalkarteniz and Lake Tengiz in 1966, where a breeding colony was found in the north-eastern part of the main deep, on the island of Chayachiy (14,000 individuals, 2500 2700 nests). In the same year, about 2000 individuals were observed on Lake Jaman-Akkol (Lebedeva \& Shevareva, 1970). But in 1966, most of the young birds died on Lake Tengiz as a result of heavy hail (Elkin, 1969).

In 1967, approximately 9500 individuals were accounted on Lake Tengiz, but in the second half of August - early September, the number of flamingos increased, up to the second half of October, due to migrations of non-breeding individuals from non-permanent summering areas to other habitats with subsequent placement after snowfall in the third decade of September: small groups of individuals began to meet on the 
many lakes and blinkers around Lake Tengiz and Lake Kurgaldzhin. It is not known, whether the flamingos nested on Lake Tengiz in 1967 and 1968 , but in 1965-1968, the number of moulted birds on the lake had not changed dramatically. In the period 1966-1971, the number of flamingos stabilised in Central Kazakhstan. Their number amounted 12,000-15,000 individuals (Lebedeva \& Shevareva, 1970).

In the ensuing arid, little water years, most of the lakes in Central Kazakhstan dried up completely, transforming into salt marshes or blinders - poachy, impassable salt marshes. In times of transgression, breeding colonies moved from Lake Tengiz to Lake Shalkarteniz (Spangenberg, 1951; Cheltsov-Bebutov, 1958; Varshavskiy et al., 1977; Krivitskiy et al., 1985), provided that it did not dry up completely (Elkin, 1969; Volkov, 1975, 1977). Since 1968, Lake Tengiz was included into the territory of the Kurgaldzhinskiy Reserve, organised on the basis of the former hunting reserve that was established to protect waterfowls on Lake Kurgaldzhin.

In 1969, a breeding colony (3500-4000 pairs, up to 2000 nests, up to 7000 nestlings of different ages of gray and white colour) was located on the eastern part of Lake Tengiz, on the sand islands Dalniy and Colonia. The former varied from $0.0035 \mathrm{~km}^{2}$ in 1969 to $0.0070 \mathrm{~km}^{2}$ in 1970 , and then again to $0.0065 \mathrm{~km}^{2}$; the latter varied from $0.0054 \mathrm{~km}^{2}$ in 1969 to $0.0080 \mathrm{~km}^{2}$ in 1970. And it disappeared in spring 1971, being completely destroyed due to ice motion. Only a few small shallows subsequently remained. Most of the young and adult flamingos stayed near the island Dalniy. But nests were absent there. In September 1969, 11,000-13,000 individuals were counted on Lake Tengiz using aerial photography (Lebedeva \& Shevareva, 1970).

In 1970, nests of flamingos were found on both islands on Lake Tengiz; the total number of breeding birds was at least 7000-8000. On the island Colonia, there were found up to 2000 nests abandoned by nestlings; the nests were made of sand and stapled by feathers (with a dominance of humeral feathers) in the upper third; the nests were located in the central, more elevated part of the island, covering an area of $4330 \mathrm{~m}^{2}$. During this period, the number of nestlings was 7000 individuals. In addition, a third breeding colony and about 500 yet non-flying nestlings were found by the aircraft near the western shore of the lake in a wide damp saltmarsh near the island
Luna (Lebedeva \& Shevareva, 1970). In August 1970, air-survey covered all lakes within the breeding region, lakes of the floodplain of lower reaches of the rivers Turgay and Irgiz, and Lake Sarykopa. The basins of Lake Shalkarteniz and Lake Aschitastysor were completely dry. A little water was left in Lake Jaman-Akkol and in a group of blinders located to the west of it, especially noticeable in the floodplain of Lake Turgay. Six flocks of flamingos (with a total number of 420 individuals) were observed in this area. During the summer migrations, separate flocks were observed for a short time on other brackish and salt waterbodies in Central Kazakhstan. Flamingos were absent on Lake Shalkarteniz and on Lake Aschitastysor. Four birds were found in the southern part of Lake Sarykopa (Lebedeva \& Shevareva, 1970).

In 1971-1972, the number of flamingos in Central Kazakhstan dramatically decreased, declining about 5 times during 15 years. In 1971, a breeding colony containing 7000-8000 individuals was located on the island Dalniy on the eastern part of Lake Tengiz; the number of nestlings at the age of 1.0-1.5 months was assessed on 7000 individuals (Lebedeva \& Shevareva, 1970). There were counted 1435 nests, up to 1500 pairs of birds nested on the salt marshes on the western shore of the lake near the island Luna; late August 1971, up to 700 large nestlings (they began to fly after a few days) were found on the shore of Lake Tengiz near the island Luna (Auezov, 1977). Subadult, non-breeding birds did not reach the nesting areas during the spring migration. In the summer they migrated along different waterbodies. During 1969-1971, more than 500 birds were ringed. All of them had adult plumage, acquired in the third year of life, with brood-patches for most of them (Lebedeva \& Shevareva, 1970).

In the Northern Caspian, the flamingos continued to nest for some time on Lake Shala-Kupa in Ryn-Peski and Lake Inderskoe (Dinesman, 1960). But by the early 1960s, these breeding colonies had disappeared; and only once, at the end of August 1962, a single bird was observed there; until 1972, no breeding colonies were found on these locations. The nesting site in the lower reaches of the river Emba also disappeared (Poslavskiy et al., 1977). Throughout May, migratory flamingos were observed in the estuary of the river Ural (Dolgushin, 1960); during the summering at the end of August 1975, 
60 birds, migrating to the west, were observed in the lower reaches of the river Ural, and early September, solitary birds were observed, migrating to the south (Gubin et al., 1977). Birds were also observed during the migration in the north-eastern part of the Caspian Sea, along the river Emba and adjacent deserts; these individuals migrated to the east, in the direction of Lake Tengiz and Lake Shalkarteniz. The arrival of flamingos in spring took place during two months: in March, the first flamingos began to appear in the South Mangyshlak in Kazakhstan, with the largest number of individuals per day from 10s - 20s days of April till the end of May (Molodovsky, 1963). On the south-western coast of the Caspian Sea, spring usually began in March, but sometimes migration of flamingos to the north had already been observed in February. Spring migration of flamingos out of the Kyzyl-Agachskiy Reserve ended at the end of April (Grekov, 1962; Morozkin, 1975). During 1959-1972, only one individual was observed once, at the end of May, in the lower reaches of the river Uil in western Kazakhstan (Poslavskiy et al., 1977). At the same time, in the Garabogazköl gulf during May - August of 1958-1972, flamingos were observed regularly: in the summers of 1968-1972, and in mid-May 1971, flocks containing thousands of birds were registered there (Poslavskiy et al., 1977).

During 1961-1970, non-breeding birds on the summering were observed on the seaside lane north of the Mertvyi Kultuk gulf where non-breeding flamingos moulted (Molodovsky, 1963; Gistsov, 2004); From late May till August 1964, 1090 individuals were counted here; at the same time in 1965, 3091 individuals were observed (Neruchev \& Khudyakov, 1967). By 1967, four breeding colonies with a total number of nests up to 1000 were found in the shoaling gulf Mertvyi Kultuk (Lankin, 1981).

Autumn migration of flamingos took place at night, and that is why it was poorly visible. It was found that flamingos migrated away from Lake Tengiz to the south-west over the lakes Kipshak, Jaman-Akkol, Onkunkol and the lower reaches of the rivers Turgay and Irgiz. In this interval of the migration route, a flamingo (ringed on Lake Tengiz) crashed on a telephone line cord $60 \mathrm{~km}$ south of the village Turgay at the beginning of September 1970. An adult flamingo (ringed on Lake Tengiz in July 1968) was killed on 7 December 1968 on Lake Aktham near the village Kazakdarya on the southern shore of the Aral Sea. A nestling flamingo (ringed on July 1970) was killed on 9 November $38 \mathrm{~km}$ west of Ashkhabad. A flamingo (labelled on Lake Tengiz during the moulting in July 1968) was killed in the autumn of the same year in Dengizskiy (Kurmangazinskiy) district of Guryevskaya (Atyrauskaya) region (Volkov, 1977a).

Summerings and winterings of the flamingo in the southern part of the Caspian Sea retained its importance throughout the period with lowering of the water level (Poslavskiy et al., 1977). In 1962-1963, the number of flamingos was 1700 individuals on winterings in the Kyzyl-Agachskiy Reserve (Oliger, 1967). In certain years, a lot of birds flocked on the coast near the Garabogazköl gulf; from mid-September to the end of October, flamingos were located in the Krasnovodskiy gulf. By mid-November, up to 12,000 individuals flocked in the Mikhailovskiy gulf and on the seacoast and its neighbourhood; they flocked here at night (Neyfeld, 1967). In November 1968, approximately 3000 individuals were accounted in the KyzylAgachskiy Reserve; in 1968-1969, the number of birds had decreased to some single individuals after a very severe wintering (Lebedeva \& Shevareva, 1970); the same significant reduction in the number of flamingos was observed along the south-eastern coast of the Caspian Sea: only 359 individuals were accounted on the wintering in the Krasnovodskiy gulf (Luri \& Sabinevskiy, 1968). In 1969-1970, 300 individuals were accounted during the wintering in Kyzyl-Agach, but 20,500 individuals were observed somewhat north - in the Krasnovodskiy gulf. In 1970-1971, 55 individuals were accounted during wintering at the seaside at the south-eastern part of the Caspian Sea; 10,000 individuals were observed in the Krasnovodskiy gulf; in 1971-1972, some single birds were seen during wintering in the Kyzyl-Agach, and 3090 individuals were recorded in the Krasnovodskiy gulf (Poslavskiy et al., 1977).

It was found that the coastal shallow waters in the south-eastern part of the Caspian Sea in conditions of shoaling became unsuitable for flamingos in feed respect, their safety conditions became worse, due to the fact that the coastline became rectilinear, devoid of gulfs and coves, and during the winter it either frosted over or exposed to strong impulses of the waves. However, in 1968, the territory of the Hasan- 
Kuliyskiy Ornithological Reserve (where the main wintering of flamingos was at that time) was expanded due to seaside areas located north (Ataev et al., 1978).

At the same time, the water reservoir Caracol with lots of islets was formed after its isolation from the Caspian Sea by the dam of a vast blinder and the discharge of waters of industrial enterprises of the city Shevchenko into the water reservoir; since 1970, it has become a place of rest during the off-season migrations of flamingos (Lankin, 1981).

In conditions of ongoing shoaling of the Caspian Sea, it was confirmed that the northern coast of the Caspian Sea has acquired feed properties satisfying flamingos; the residence sites for birds during summerings and migrations were rarely visited by people and they were outside the zones of economic use of the water area (Krivonosov et al., 1978). Rarely massive clusters of migratory flamingos were observed in the northern Caspian region: from late August to mid-October 1977, a flock of more than 1000 young and adult birds stayed in the shallow water of the water reservoir Chograyskoe in Stavropol Krai (Khokhlov, 1988). However, the conditions for wintering near the Krasnovodsk city were unsuitable: when the Mikhailovskiy gulf and the shallow water of the Severnyi Cheleken frosted over, the flamingos migrated to the water area of the Krasnovodskiy gulf, which was deep-water, shallow was almost absent, and this site froze up completely only in severe winters, like in 1969 and 1972. However, winterings in the Krasnovodskiy gulf formed as forced, because this gulf periodically froze up, too; additionally, high salinity of the water and the death of algae and invertebrates (main food of flamingos) were due to the progressive shallowing of its southern part. Therefore the flamingos were forced to migrate further to the south in severe winters, beyond the Caspian Sea, because they did not find favourable conditions on the south-east coast. At the same time, a significant number of birds died during the cold spell (Poslavskiy et al., 1977).

The assumption that a certain number of individuals of the northern part of the Asian population of flamingos continued to winter outside the (former) Soviet Union, was confirmed by the returns of rings as a result of the bird banding during 1967-1971 (Lebedeva \& Shevareva, 1971). A weakened bird, ringed in 1967 on Lake Tengiz, was caught after the storm in January 1968 on the Turkmenian coast of the Caspian Sea. Flamingo-yearlings, ringed on Lake Tengiz, were found at the waterbodies at a distance of at least $1000 \mathrm{~km}$ : in the winter of 1970-1971, in Egypt (Lake Manzala), Iraq (near the city of Kut), in Iran (Lake Urmia and Lake Makharlu; Gorgan gulf of the Caspian Sea); the next winter, 1971-1972, single ringed juveniles were observed on Lake Urmia and near the city of Pahlavi and the settlements Sary and Bekhshekhr, in the estuary of the river Kura. Perhaps such far migrations to the south did not occur every year and these were associated with the weather conditions of Caspian winterings; but this area certainly remained a fragment of the winter range of the flamingo (Volkov, 1977b).

In the 1970s, the whole northern part of the Asian flamingo population was estimated at 13,400-15,000 adult individuals (Elkin et al., 1975; Volkov, 1977a), taking into account that the vast majority of individuals was accounted within Central Kazakhstan. Small floodplain freshwater lakes began to be filled as a result of early and abundant floods after snowy winters in areas of the rivers Sary-Turgay, Turgay, Irgiz, Uly-Zhilanshik; and beginning from 1970, the next phase of water cut of lakes began in Central Kazakhstan. In 1969, up to 2000 pairs nested on Lake Tengiz; in 1971, up to 13,400 adult birds were accounted; of them 7000-8000 birds nested on the island Dalniy. After severe floods, in 1971-1972, Lake Jaman-Akkol was significantly filled and desalinated, as well as the basin of Lake Shalkarteniz (Volkov, 1977a). In 1972, all waterbodies of the Central Kazakhstan were filled with water (except Lake Aschitastysor); and up to 9000 individuals of flamingo were registered on them. Up to 50 nomadic individuals were observed in the open salt waterbody southwest of the sands Tosum; approximately 100 individuals were seen on Lake Jaman-Akkol. The level of Lake Tengiz was lifted up to $0.5 \mathrm{~m}$ (compared with the level in 1970); and the island Dalniy, where flamingos nested earlier, proved to be flooded. As a result, in 1972, flamingos appeared on the lake in smaller amounts than usual; only about 800 individuals were accounted using the aerial photography (Red Data Book of the Kazakh SSR, 1978), but nesting was not observed (Volkov, 1977a). Early May, flamingos almost completely flew away from Lake Tengiz, having moved to Lake 
Shalkarteniz. A colony was formed on the island in the western part of this lake. It consisted of 8000 adult and 4000-5000 young individuals older than 1.5 months. By the autumn of 1973 , Lake Shalkarteniz dried up; and flamingos together with the grown nestlings were forced to migrate to small freshwater lakes in the delta of the river Turgay: Lake Caracol and Lake Kurdym; the flamingos used Lake Kipshak (Azhibeksor, Solenoe), Lake Kirey and Lake Tuzaschi for feeding. As a result, a sharp decline in the number of individuals in the whole northern part of the range of the Asian population was observed (Elkin et al., 1975; Lankin, 1981). After that, in 1975, the flamingos nested on Lake Shalkarteniz again; but then the breeding colony disappeared for five years (until 1981), although the lake kept the significance for them as the place of summering. At the same time, flooding of salt marshes on the eastern shore of Lake Tengiz occurred; its area increased significantly; and flamingos settled on the emerged system of islands: a large cluster of 4000-5000 individuals (adults and juveniles older than 1.5 months) was found near one of the islands in the western part of the lake (Volkov, 1977a; Krivitskiy et al., 1985).

In 1974, up to 5000 flamingos were accounted on Lake Tengiz (Red Data Book of the Kazakh SSR, 1978), and up to 9000 adult birds were accounted in the whole of Central Kazakhstan due to their redistribution to other habitats (Volkov, 1977a); in total, 12,000 individuals were accounted in the northern part of the Asian population (Elkin et al., 1975). In 1975, up to 9000 adult birds and 1430 nests were registered on Lake Tengiz; in 1976, 5000-9000 individuals were observed (Volkov, 1977a); in 1977, 13,500 individuals were counted; in 1978, 35,00036,000 individuals were registered; in 1979, 54,600 adult birds were counted, of which up to 14,000 pairs were nesting birds (Andrusenko, 1980, 1981; Red Data Book of the Kazakh SSR, 1978). In 1977, some birds laid eggs directly on the sand, not all breeding pairs being able to build cone-shaped mud nests (Rusanov et al., 1991; Rusanov, 2002).

Birds actively used the northern migration route as a result of the placement of the majority of individuals of the northern part of the Asian population of flamingos on the waterbodies of Central Kazakhstan. During the spring migration, flocks with different numbers of birds were observed: in the spring of 1972 , migratory flocks of flamingos containing up to 60 individuals were observed on the plateau between Bolshie Barsuki and Malye Barsuki (Varshavskiy et al., 1977). Weak migration was registered on the eastern shore of the Aral Sea in the area of the Kyzyl-Kum (Berezovskiy, 1983) and along the river Syrdarja (Volkov, 1977a). In May 1974, 400 individuals were observed in the natural landmark Zhabinka near the bend of the river Emba; several flocks containing 200400 individuals were recorded in the coastal part of the delta of the river Emba; ibid, in May 1978, a wounded bird was found; in May 1976, 600 individuals were registered in the desert south of the river Emba (Neruchev, 1991). In spring, some individuals have shied away from the traditional migration route and penetrated into the eastern borders of the Rostov region through waterbodies of the Manych (Kazakov et al., 2004); they were observed in the estuary of the river Volga, in Kalmykia, Krasnodarsky Krai and Stavropolsky Krai (Spangenberg, 1951; Dolgushin, 1960). During 1970-1980, approximately 8000 adults and juveniles were ringed on Lake Tengiz; of these, 70 birds returned to the lake in the Korgalzhyn Reserve (Lebedeva \& Shevareva, 1970).

By mid-October, the main part of the individuals from Central Kazakhstan already migrated away, leaving the nesting sites and summerings; only small groups of flamingos (which have not completed moulting) remained - about 300 individuals were counted in the largest of such flocks (Azarov \& Zhiryakov, 1976). Sometimes separate flocks, containing 300-500 (up to 2000-3000) individuals, circled for a long time above the large freshwater lakes near the river Turgay, from where they flew away late October (Garbuzov, 2000). In mid-October 1973, autumn migration of small flocks of flamingos was observed in the south-west direction through Western Tien Shan to Kazakhstan, Uzbekistan, Kyrgyzstan and partly Tajikistan (Gistsov et al., 1977). Late September - early October, a weak autumn migration through deserts of the Northern Caspian region was recorded. Flamingos stayed near the western coast of the peninsula Buzachi until November. In mid-September 1970, approximately 2000 individuals were seen in the Mikhailovskiy gulf, of which young birds amounted to one-third; On 23 September, already about 10,000 individuals were account- 
ed here, amongst them young birds, amounting not more than a dozen (Poslavskiy et al., 1977). In September 1974, about 4000 individuals were counted near the Zaburunskaya hirst. On 30 June 1977, 15,000 flamingos were observed here; they were represented by flocks containing at least 500 birds (Krivonosov et al., 1984). It was found that yearlings ringed on Lake Tengiz, spent the winter on waterbodies, separated from each other by at least $1000 \mathrm{~km}$ (Volkov, 1977a,b). Data obtained as a result of bird banding and visual observations, gave the reason to assume the existence of a straight migration route from the lower reaches of the river Turgay to the south-eastern tip of the Caspian Sea and Iran through the Aral Sea region (Volkov, 1979; Karavaev \& Belousov, 1983; Andrusenko, 1986, 2007). In spring, the young flamingos penetrated in a small number into the breeding sites in Central Kazakhstan, staying along the migration route and on the winterings. The first returning birds on Lake Tengiz were registered since the end of March - early April until the end of May. Immature birds were observed in the lower reaches of the river Turgay, on Lake Jaman-Akkol, Lake Kyzyl-Kol and on the southern part of Lake Sarykopa (Volkov, 1977a; Auezov, 1977; Auezov \& Vinogradov, 1986).

Nomadic individuals were observed in small flocks around the east coast of the Caspian Sea (Vasiljev, 1976a); on 2 July 1970, 19 individuals were observed in the Mikhailovskiy gulf; in 1971, a flock containing 200 birds was seen in the Saymonov bay near the town Krasnovodsk; on 28 May, seven birds were found in the northern part of the Krasnovodskiy gulf (Poslavskiy et al., 1977). In 1970-1971, an attempt of flamingos to nest on Lake Sarykamysh was observed under decrease of the water level and appearance of shallows with swampy islands near the mouth of the river Darjalka; but the colony was lost as a result of poaching and the subsequent increase of the water level in the lake (Chernov, 1990; Bukreev, 1997); the remaining individuals flew away to other waterbodies: in September 1971, one dead bird was found on Lake Solenoe near the village Chistovskoe in the Severo-Kazakhstanskaya region (Vilkov, 2010). In September - October 1971, flamingos were found in a large number near the Garabogazköl gulf. In 1971, they appeared in the Krasnovodskiy gulf in mid-September: on 5 October, the first flock of 58 birds flew away to the south-west; by 12 November, 9500 individuals stayed in the Mikhailovskiy gulf and 2500 individuals stayed on the sea coast near this gulf; on 15 November, the last two flocks, containing respectively 250 and 42 birds, flew above the island Osushnyi (Poslavskiy et al., 1977). In certain years during the autumn migration along the east coast of the Caspian Sea, flamingos stopped for 1-1.5 months at the mouth of the former Mertvyi Kultuk gulf, on the coast near the Garabogazköl gulf and in the Krasnovodskiy gulf (Poslavskiy et al., 1977).

Due to the continuing decline of the sea level, the location of the breeding colonies changed again: during 1968-1972, the flamingos nested at the mouth of the former Mertvyi Kultuk gulf (Poslavskiy et al., 1977) which had dried up to this time. Late June, a lot of flying juvenile birds appeared at the seaside lane to the north of the Mertvyi Kultuk gulf; in August - September during 1968-1972, mixed (adult and young birds) flocks were observed; they stayed at the seaside and blinders of the desert till mid-October (Neruchev \& Khudyakov, 1967).

In 1975-1976, only a small number of individuals wintered on the coast near the village Chikishlyar and in the Mikhailovskiy gulf; in 1976, the summerings of flamingos were located in the Garabogazköl gulf, and (in smaller amounts) in the Krasnovodskiy gulf (Poslavsky et al., 1977); they moved to the Mikhailovskiy gulf during the summer (Ataev et al., 1978). After 1976, the Mikhailovskiy gulf dried up; and the majority of flamingos was concentrated in the following gulfs: Balkhanskiy, Krasnovodskiy, Severnyi Cheleken (Lankin, 1981). In 1977, the flamingos did not breed in the southeastern part of the Caspian Sea, but in 19771978, 6000-16,000 individuals wintered here (Vasiljev, 1976b).

Regular registration of birds during all seasons (and especially in autumn) on the west coast of the Caspian Sea and in the valley of the river Manych were associated with the existence of a migration route over the sea and along the coast (Volkov, 1979; Mikheev, 1985). Most of the flamingos, which wintered in Azerbaijan, crossed the Caspian Sea at its southern and middle parts. Only a minor part of birds migrated along the western coast of the Caspian Sea up to southern Dagestan, and in certain years - up to the Agrakhanskiy gulf, from where they flew to the eastern sea coast. Late March and 
early April, large clusters of flamingos were observed on Lake Aji in Dagestan (Kazakov et al., 2004). From late March to early May the spring migration took place in the estuary of the river Samur in the south of Dagestan, while the main part of birds migrated in March and early April (Butjev et al., 1989; Mikheev, 1997). After severe winterings, the spring appearance of the first flamingos on the sites of nesting and summering was registered at later dates than usual (Andrusenko, 1979).

In 1977, three colonies of flamingos (with a total number of several thousands of nests) were found in the Mertvyi Kultuk gulf: the first of these was located 3-4 km northwest of Jaman-Airakty mountain, $40 \mathrm{~km}$ along the river Manash, the second colony was located approximately $20 \mathrm{~km}$ to the north of the first colony, and the third of these on the island east of the Komsomolets gulf. But in 1978, the Komsomolets gulf and most of the Mertvyi Kultuk gulf dried completely due to the continuing declining of the water level in the sea. The colony in the Komsomolets gulf disappeared, but the two colonies (in which 650 and 800 nests were registered on 22 May 1980) remained in the Mertvyi Kultuk gulf (Lankin, 1981). In summer, the non-breeding birds concentrated north of the Mertvyi Kultuk gulf and south - in the Garabogazköl gulf; they were observed in a small amount in the Krasnovodskiy gulf and on the south-east coast of the Caspian Sea (Poslavskiy et al., 1977).

Since 1978, the increase of the level of the Caspian Sea had begun as a result of damming up of the strait of the Garabogazköl gulf (powerful evaporator of Caspian water) and an increase in rainfall onto the mirror of the sea and in basins of rivers flowing into the Caspian Sea (mainly - the river Volga) with exceeding of the long-term rate of inflow of river water for $10-15 \%$. During the next two years, its level increased more than on $1.5 \mathrm{~m}$, reaching the highest level of $28.4 \mathrm{~m}$ and remaining on the level of not lower than $24.05 \mathrm{~m}$, even late July 1980 (Vakhsman, 1982). This led to the flooding of some shallows, and to the formation of others; that had changed the configuration of the shoreline and location of summerings and winterings of flamingos on the seashores.

During the spring migration along the northern route, observations of the flamingos began to occur repeatedly. In mid-April 1979 twenty individuals were observed in the natural land- mark Zhamanushkan on artesian waterbody (Samarin et al., 1991). In mid-May 1979, 30 individuals were seen near the well Zhanasu and mountains Zhiltau (Neruchev, 1991). In mid-March 1980, more than 1000 individuals in two flocks were observed on the water reservoir Caracol (Lankin, 1981). In mid-April 1980, two birds were seen in the city of Ust-Kamenogorsk; at the beginning of October 1982, a single young individual was caught on the river Ulba near the city of Ust-Kamenogorsk. In mid-May 1983, two birds were observed at the same place during migration (Shcherbakov, 1991). In midApril 1981, 50 individuals were observed in the natural landmark Dzharchik. In mid-May 1982, up to 100 individuals were seen in the natural landmark Taylan. In mid-May 1983, 20 flamingos were found in the natural landmark Shubartpaly (Samarin et al., 1991). In May 1985, several flocks were observed on the lakes of the Naurzumskiy Reserve (Bragin \& Bragina, 2002). In May 1986, four migratory birds and 25 feeding individuals were observed on the river Turgay and on Lake Kyzyl-Kol in the Turanskaya lowland (Khrokov, 1991). In April 1987, five individuals were observed during migration along the south-western migration route in the drainage basin Kenderlisor on the territory of the Ustyurt Reserve (Dyakin, 1991).

In mid-May 1980, five individuals were observed during the spring migration along the southern migration route on Lake Sorbulak in the neighbourhood of Alma-Ata (Khrokov, 1991); in April 1987, the migration of 58 birds was observed on the river Amudarja in the neighbourhood of the city Chardzhou (Stotskaya \& Krivenko, 1988); in May 2000, two individuals were found in the Maybiryuk gulf in the western part of Lake Alakol (Berezovikov \& Anisimov, 2002). Not annually flamingos were observed in small groups on the Aral Sea; there are data on observations in the Amudaryinskiy Reserve, in the Fergana Valley, in the valleys of the rivers Zeravshan and Syrdarja (Meklenburtsev, 1987).

In 1979, the number of the northern part of the Asian population of flamingos was estimated at 54,600 individuals (Khrokov, 1991). During the summer of $1976-1982,1500$ to 15,000 individuals were observed on the north-east coast of the Caspian Sea, including 200 individuals in the blinder Caracol (Lankin, 1981). In the 1980s, the total number of flamingos during the summer moulting had reached 50,000 
individuals near the north-eastern coast of the Caspian Sea (Rusanov, 2004), including those in September 1982, up to 20,000 individuals were observed from the estuary of the river Ural to the river Emba (Berezovikov \& Gistsov, 1996/1997; Gistsov, 2001). In the early 1980s, flamingos nested during one year at three places on the territory of the Kyzyl-Agachsky Reserve (Kustanovich, 1986). In September 1983, about 50,000 individuals were observed only in the summering from Zaburunskaya hirst to the estuary of the river Ural (Berezovikov \& Gistsov, 1996/1997; Gistsov, 2001). A number of 73,000 individuals were registered along the entire northern and north-eastern coast of the Caspian Sea: this was the largest number for this period, including 22,000 pairs observed in breeding colonies (Krivonosov et al., 1984). Presumably, in 1985 the flamingos nested also on the northeast coast of the Caspian Sea from the estuary of the river Emba to the Buzachi peninsula (Stotskaya \& Krivenko, 1988).

During the period of the highest concentration of birds in September, the total number of the migratory clusters of flamingos near the coasts of the Northern Caspian region amounted 73,000 individuals in $1983 ; 65,500-70,400$ individuals in 1984; 27,500 individuals in 1985; 51,200 individuals in $1986 ; 35,600$ individuals in $1988 ; 17,900$ individuals in 1989 , where a large part of the population (1100 individuals in 1988) was at breeding sites outside the seacoasts (Rusanov, 2004). In September 1990, clusters of $30,000-35,000$ individuals $(2 / 3$ of the northern part of the Asian population) were observed in the delta of the river Ural and on the seacoast from the river Emba to the Komsomolets gulf (Rusanov et al., 1991; Gistsov, 1994). However, flamingos in the delta of the river Volga remained rare vagrant birds, and it was accidentally vagrant on western sub-steppe lakes of the Volga floodplain, and in the VolgaAkhtuba floodplain (Reutsky, 2014): single individuals were seen during seasonal migrations only twice - late October 1997 and late May 2006 (Chernobay, 2004).

Non-breeding birds were located on the summering mainly along the north-eastern coast of the Caspian Sea (Gistsov, 2004), from where the dispersal of individuals was observed by small flocks, containing mainly subadult individuals. During the summer migrations at the end of July 1980 two birds were observed dur- ing feeding on Lake Bartyldakty in the delta of the river Emba (Neruchev, 1991); in June 1978 and 1982, single and pairs of non-breeding juvenile birds were observed in the Pavlodar region on the lakes of Novotroitskoe and Tleuberdy; ibid, in September 1978, five individuals were observed (Solomatin, 1991). In 1982, a mass death of flamingos was recorded from the northern coast of the Caspian Sea. Separate individuals were found in the lower reaches (natural landmark Itbalyk) and in the estuary of the river Ural (Klimov, 1991). In June 1983, seven birds were seen on the north-eastern coast of the Caspian Sea in the neighbourhood of the village Karaton. And 10 individuals were observed in the natural landmark Deukara on an artesian waterbody (Samarin et al., 1991). In July 1983, 35 individuals during feeding were seen on Lake Akkol (Neruchev, 1991). In August 1983, 18 adult birds were observed on Lake Jarbas in the Aktobe region (Auezov, 1991). In 198717 individuals were registered on Lake Shelegino (Vilkov, 2010). In June August of 1992-1997, small flocks of the flamingo were seen on waterbodies of the Armenian plateau (Adamian \& Klem, 1999).

In 1987, flamingos were observed during autumn migration along the south-western migration route in the Ferghana valley, on the Aral Sea, in the valleys of the rivers Zeravshan and Syrdarja in the Amudaryinskiy Reserve (Meklenburtsev, 1987). During the autumn migration along the southern migration route in 1984, 15 individuals (migrating to the south-west) were seen in the estuary of the river Kurchum near Lake Zaisan; ibid, in November, one killed bird was found; another bird was found ten days later (Shcherbakov, 1999). In 1987, a single bird was killed in the natural landmark Karasu in the west of Lake Alakol; ibid, in October 1989, another bird was killed on the northern shore of the lake (Berezovikov \& Anisimov, 2002).

From April till October, up to 20,000 individuals were registered in the Komsomolets gulf, and up to 40,000-50,000 thousand individuals were observed during the migration. On 13-14 April, 2002, 20,600 individuals were counted on aviaroutes in the Mangyshlak gulf, the Komsomolets gulf and the Mertvyi Kultuk blinder; up to 40,000-50,000 individuals - in autumn; up to 20,000 birds - during wintering; and 17,300 individuals - on 17-18 April, 2004 (Gistsov, 2004). Winterings of flamingo were observed on 
the eastern coast of the Caspian Sea and on Lake Caracol near the city Aktau (Gistsov, 2004).

In the late twentieth century flamingos did not nest in Turkmenistan yet (Bukreev, 1997). During this period, from 5000-6000 to 15,000 16,000 individuals annually wintered in the Turkmenbashi gulf in the Krasnovodsky Reserve (Red Data Book of the Altayskiy Krai, 2006).

In 1980-1987, flamingos were observed on wintering on the Ossetian plain (Komarova \& Komarov, 1988), where flocks containing from 50 to more than 1000 individuals were seen (Khokhlov, 1988). Single individuals rarely delayed on wintering in the south of Dagestan. Since 1982, the flamingos nested in the Kyzyl-Agachsky Reserve on the south-western coast of the Caspian Sea (Litvinova et al., 1984); in 1982 and 1983, the annual number of nesting birds was about 200 pairs (Babenko, 2005); but in 1984, the breeding colony disappeared due to predation of the jackals Canis aureus (Linnaeus, 1758). In 1985, the colony was not found there, but adult and young birds were seen here in July of the same year (Stotskaya \& Krivenko, 1988). In the summers of the 1980s, single individuals were repeatedly observed in the lower reaches of the rivers Terek, Sulak, ShuraOzen and on Lake Aji in Dagestan; at the same time, flocks of flamingos were seen in summering in the valley of Lake Manych-Gudilo; single individuals were seen on waterbodies of the Rostov region and Stavropol Krai (Mikheev, 1985; Khokhlov, 1988; Pishvanov \& Prilutskaya, 1988).

The number of flamingos at winterings in the Kyzyl-Agachsky Reserve fluctuated greatly over the years depending on the weather conditions: 13,500 individuals wintered in 1984-1985; 3300 individuals - in 1989-1990; 12,970 individuals - in 1990-1991; 8900 individuals - in 1994-1995; 5200 individuals - in 1995-1996 (Patrikeev, 2004). In January 2004 approximately 6000 individuals wintered in the Kyzyl-Agach gulf; 3500 individuals - on Lake Adzhino-ur; 1200 individuals - on Lake Akgël; in total, about 11,000 flamingos wintered in Azerbaijan in January 2004. By the early XXI century, it became apparent that the largest wintering of waterfowls and shorebirds in Europe is located in the territory of Lenkoranskaya lowland, in the KyzylAgachsky Reserve (Babenko, 2005).

Early January 2006, a single bird, flying to the south, was recorded for the first time after four years of regular winter observations on the seacoast in the estuary of the river Samur; at the same time, a single flamingo stayed on a shallow of Lake Aji; early March 2006, a single bird was observed in the valley of the river Kherota in the outskirts of Adler. Early June 2007, one subadult bird rested in the northern shallow part of the Sulak bay; late June 2007, 12 individuals were observed on shallow spills in the northern part of Lake Aji - at the same place where single birds were repeatedly seen during summerings in previous years (Bragin \& Bragina, 2002).

In 1984-1985, an unusually severe winter occurred in the northern part of the Middle East, where the winterings of flamingos were located. As a result, for flamingos the way there was closed due to unfavourable weather conditions; therefore the flamingos were forced to continue the migration from pre-wintering sites and wintering clusters (on the southern coast of the Caspian Sea and lakes in Iran) to the west; therefore birds appeared near the southern coast of Cyprus and they gathered on the lakes in the neighbourhood of the cities Larnaca and Limasol in a number of approximately 20,000 individuals (Kustanovich, 1986).

Flamingos were repeatedly observed during the spring migration along the northern migration route: for example, in May 1990, 1991, 1992 on the lakes of the Naurzumsky Reserve (Bragin \& Bragina, 2002); in May 2004, one individual was killed on Lake Zhalanashkol in the Dzhungarskie vorota (Berezovikov \& Levinskiy, 2005); early May 2009 two individuals were observed in the natural landmark Chubar-Tyubek on the western shore of Lake Alakol (Berezovikov, Levinskiy, 2009); early May 201014 and 16 birds were observed on Lake Sandykbaysor and Kurgaldzhin, respectively (Khrokov, 2010); late March 2015 a mass death of flamingos was observed along the migration route after a dust storm on Lake Karakol.

The staying of flamingos on the continental lakes of Central Kazakhstan was determined by factors, which formed the hydrological regime of these waterbodies. Distributing themselves along the migration route and on winterings, the young birds penetrated into the nesting sites in small number. Immature birds were observed in the lower reaches of Turgay, on Lake JamanAkkol, Lake Kyzyl-Kol and on the southern part of Lake Sarykopa (Auezov \& Vinogradov, 1986). During the nesting period, mature individuals were located in a vast majority in the territory of Central Kazakhstan. During this period, 70,400-73,000 individuals were annually 
counted within the northern part of the range of the population, mainly in Kazakhstan (Rusanov, 2004); including 11,000-22,000 pairs counted during the breeding season (Stotskaya \& Krivenko, 1988); at the same time the moulting of flamingos (4500-5000 individuals) was observed at the location of the breeding colonies (Andrusenko \& Zhuliy, 1978).

In $1979,50,000-55,000$ birds arrived on Lake Tengiz, but of these, only 11,400 pairs built nests (Kustanovich, 1986). In 1980, the breeding colonies on Lake Tengiz were demolished during a severe storm. In 1981, the flamingos did not nest on Lake Tengiz, having moved to Lake Shalkarteniz and the blinder Mertvyi Kultuk. Earlier it was found that flamingos can change the nesting sites depending on hydrological conditions, but they nested quite constantly in Central Kazakhstan (Andrusenko, 1986). During the summer period until early September 1980 and 1982, 500-600 birds were located on Lake Sor (blinder Zhanakurlusskiy) and Lake Karatay. In 1984, 27,500 individuals were counted on Lake Tengiz and blinders of Central Kazakhstan, of which up to 11,000 pairs participated in reproduction (Stotskaya \& Krivenko, 1988; Rusanov, 2004). Early August 1985 about 300 flamingos were located on Lake Kiyakty in the northern part of the Tengizskiy district; from spring till early September 1985 approximately 60 flamingos were located on Lake Kultansor and Lake Tatysor; their visits (for feeding) to the lakes Kyshpak, Kerey, Tuzaschi in the Tengizskiy region was noted earlier (Dolgushin, 1960; Rusanov, 2004). According to the counting of birds in 1986, 22,179 flamingos lived on the territory of Kazakhstan (Stotskaya \& Krivenko, 1988).

During the summer migrations in 1996, 15 individuals were observed on Lake Pobeda near the village Tselinnyi (Erokhov \& Berezovikov, 2009); in June 1997, 12 birds were feeding on Lake Semilovo (Vilkov, 2010); in August 2011, 30 individuals were seen on the river Bukhtarma in the western foothills of the Altai (Starikov \& Vorobjev, 2011). During the summer period, from 1993 to 2003, flamingos (from 100 to 500 individuals) were observed during feeding on Lake Kypshak and Aschitastysor and on shallow blinders located to the south of Lake Kultansor. In 1999-2004, systematic censuses of birds were carried out on the waterbodies of Central Kazakhstan (Schielzeth et al., 2008); they confirmed that the Korgalzhyn Reserve is the key area for most of the waterfowl and shorebirds known in this area. In the early XXI century up to 15,000 flamingos were counted in total in Central Kazakhstan (Red Data Book of the Altai Krai, 2006), including 2500 to 11,500 nesting birds (Nazarenko \& Bessonov, 2009).

In 2011, the north-eastern part of Lake Tengiz (shallow waters of the Maly Teniz) dried up completely; a lane of drying was bared at the edges of the remainder of the water area; the redistribution of feeding sites occurred; flamingos in small groups were visiting the saltwater shallow waters in gulfs of Lake Esey. In 2012, there was a complete drying up of the lakes Saumalkol, Jumay, Sandykbay-sor, Maly Teniz, Kipshak, Kirey, as well as the deltas of the rivers Nura and Kulanotpes. The level of the Bolshoy Teniz decreased to about $150 \mathrm{~cm}$; and Lake Tengiz was transformed into a vast area of mud shallows. However, in 2012 the occurrence of flamingos on the waterbodies of Central Kazakhstan did not change: a colony from 2000-3000 individuals was still located on Lake Bolshoy Teniz on the island located opposite the village Mayshukyr; throughout the summer the flamingos did not commit any migration, feeding at the same place (Berezovikov et al., 2014).

By the end of this period, a colony on Lake Tengiz (25,000-36,000 individuals) was the only one in the northern part of the range of the Asian population, where reproduction of the flamingo occurred (Berezovikov, 2012, 2014); in $2015,36,000$ individuals were counted in total, mostly on Lake Bolshoy Tengiz.

In this period, Artemia salina (Linnaeus, 1758) (food for the flamingo) had appeared as part of the invertebrate fauna of the Aral Sea and in most waterbodies near the Aral Sea due to the draining and intensive salinisation of the Aral Sea. As a result, the number of flamingos (which were located on the rapidly drying Aral Sea) increased; a permanent summering was formed there. In 2002, 5 immature individuals were seen on Lake Sudochje on the left bank of the delta of the river Amudarja (Kreytsberg, 2008). In June 2007, two colonies of flamingos containing 300 and 500 adults and big nestlings were found on the shoaling seacoasts of the east and west side of the Aral Sea; in the summer of 2009 a colony on the East Aral had disappeared as a result of its complete drying. Late May 2009 1370 flamingos were observed during feeding in shallow waters of the southern part of Lake 
Akushpa and another 270 birds were recorded in the northern part of the lake; late June 2009 500 adult birds were seen here during feeding, but the search of colonies was not conducted on the inaccessible swampy eastern shores. Early June 2009300 individuals were observed on one of the shallow Akpetkinskie lakes (Ten et al., 2009). In August 2011-2013, flamingos were observed at the Aral Sea; the birds, in groups of 30-110-200 individuals, migrated for feeding to the shallow waters of the Maly Aral in the estuary of the river Syrdarja near the Kokaralskaya dam and to Lake Tuschibas of the Bolshoy Aral Sea (Berezovikov, 2012, 2014).

By the mid-1980s, it became known that the autumn migrations of the flamingo from habitats of Central Kazakhstan begin from $10 \mathrm{~s}$ - 20s days of July by undirected summer migrations of young birds and adult birds that lost their own clutches of eggs (Andrusenko, 1986). During the autumn departure, large flocks and clusters containing up to 2000-4000 individuals (mostly young birds) were observed in the nesting areas until late October - early December; and small groups and separate individuals were recorded considerably later, up to 20 January (Andrusenko, 1986). One of the major limiting factors for the greater flamingo was death during cold spells on the winterings; a part of the population was perishing during the autumn migrations during sudden cold snaps due to the arrival of cold air fronts that accompanied by prolonged snowfalls, blizzards and frosts. This led to the death of birds that delayed at the north of Kazakhstan until the first half of November, like in 1998 and 1999 (Berezovikov, 2001). During the autumn migration along the northern route early October 1997, a flock containing several dozen of individuals was observed on Lake Tyuntyugur; five juvenile birds lagged of this flock; in mid-October 1997 five individuals were observed on Lake Beskaska, while another four individuals were seen on Lake Kulykol; in October 1999 a single individual was observed in the estuary of the river Urzhar near the village Kamyskala-Rybachje (Berezovikov \& Anisimov, 2002; Erokhov \& Berezovikov, 2009); in 1999, two individuals were registered on the river Ulba in the neighbourhood of the city of Ust-Kamenogorsk (Starikov \& Vorobjev, 2011); in September 2002, 20 individuals were seen on the northern shore of Lake Alakol (Berezovikov \& Anisimov, 2002); in November 2014 a single bird was observed in the neighbourhood of the village Kosshy in the national park Burabay.

Some birds migrated from Lake Tengiz to the west: over Lake Shalkarteniz and Lake Jaman-Akkol, middle reaches of the river Emba, the north-eastern part of the Caspian Sea, Mangyshlak peninsula. In October 1972 a flock containing approximately 150 birds was observed in the eastern part of the delta of the river Volga, bordering to the marine shallow waters of the northern coast of the Caspian Sea (Rusanov \& Krivonosov, 1988). In August 1982 and 1983, large clusters of flamingos were observed between the deltas of the rivers Ural and Volga along the northern coast of the Caspian Sea (Krivonosov et al., 1984).

The northern coast of the Caspian Sea is a place of gathering for summering of adult and subadult individuals which did not participate in reproduction. During the autumn migration mentioned above, non-breeding birds joined breeding birds and their yearlings (arriving from the nesting sites) on lakes and blinders of Central Kazakhstan. From here some birds migrated along the east coast to the south (Andrusenko, 1986), the remaining individuals crossed the Caspian Sea in the middle and arrived on the west coast near Lake Aji in southern Dagestan. After a short rest, the flamingos migrated to the Kyzyl-Agach gulf, since the maximum of the autumn migration and arrival times there were recorded late October (Morozkin, 1975; Butjev et al., 1989). The autumn migration in southern Dagestan (in the estuary of the river Samur) took place in October - November, but the major part of the birds migrated in the second half of October. The flamingos did not stop here and they were flying almost exclusively above the sea, in flocks of 10-15 to 500 individuals (Butjev et al., 1989), often - up to 250 individuals, usually, separately of birds of other species. In 1987, flocks (700 individuals in total) were observed during migration in Dagestan (Pishvanov \& Prilutskaya, 1988). Flamingos migrated away from these places along the western coast of the Caspian Sea for the wintering to the territory of Turkey, Iran, in the Middle East and in North Africa: a flamingo (ringed on Lake Tengiz in 1980) was found in Tunisia (Khrokov \& Koshelev, 1989). In the mid-1990s, approximately 10,000 individuals were counted at one of the end points of the migration route of flamingos during the wintering in the Protected Area Zaranik in Egypt (Salama \& Grieve, 1996). 
Sometimes some single individuals and small flocks were flying westward across the North Caspian region; the main migration ended there in October (Rusanov, 2002). These birds stayed in autumn on the waterbodies of Kalmykia, Stavropol Krai and Northern Dagestan (Khokhlov, 1988; Pishvanov \& Prilutskaya, 1988). In rare cases, massive clusters of migratory birds were observed here. From here, flamingos migrated to the winterings on the north-eastern and northern coasts of the Mediterranean Sea.

A small portion of birds migrated from Lake Tengiz at first to the south-west up to the south coast of the Caspian Sea and then to the south and southeast to Afghanistan, Pakistan and India. Numerous observations of small groups and single individuals of flamingos in this direction evidenced about this fact (Abdusalyamov, 1971; Gistsov et al., 1977; Andrusenko, 1986).

Under favourable weather conditions during the autumn migration, a part of the birds (sometimes quite large, sometimes it was only a few dozen of birds or even some individuals) remained on the wintering in areas of the traditional migration route without reaching the final destination. Under conditions of a regular mild winter, their winterings were successful, without significant quantitative losses; however, a significant part of them or even all individuals wintering in these places died under deterioration of conditions.

Spring migration of flamingos to the nesting sites and summerings occurred in the opposite direction. Since flamingos have a pronounced geographic conservatism, they tend to return to places where they were on nesting sites and summerings earlier (Isakov, 1948b; Spangenberg, 1951; Grekov, 1962). In this regard, the migration route from west to east was actively used: from late March to early May, the spring migration took place in the estuary of the river Samur in the south of Dagestan, and the main mass of birds migrated in March and early April (Butjev et al., 1989; Mikheev, 1997). Most of the flamingos, which wintered in Azerbaijan, crossed the Caspian Sea in the southern and middle part. Only a small proportion of birds migrated along the western coast of the Caspian Sea to southern Dagestan, and in certain years up to the Agrakhanskiy gulf, from where they were flying to the east coast of the Caspian Sea. In spring, some birds apparently evaded from the traditional migration route and they were penetrating into the eastern borders of the Ros- tov region over the Manych waterbodies (Kazakov et al., 2004). On 25 May 1980, a flock of 300 birds was observed in the eastern part of the delta of the river Volga in the estuary of the Ganyushkinskiy raceway (Rusanov \& Krivonosov, 1988). The main spring migration route of flamingos was passing to the breeding sites on Lake Tengiz and other waterbodies in Central Kazakhstan: late April - early May the migration of flamingos was observed at high altitude in groups of 200-400 individuals from shallow waters of the Caspian Sea to the east - north-east along the valley of the river Emba and through the adjacent desert (Neruchev, 1991). At the same time all individuals, killed during the spring migration late May, had large fat deposits: fat (in 10-mm layer) covered the entire body, including the back and chest muscles (Isakov, 1948a), which indicated that in most cases, in the absence of extreme conditions, flamingos used the wintering time for preparation to the spring migration, reproduction and summer.

\section{Discussion}

The whole Asian population of flamingos, which nest in Southwest Asia from West and Central Turkey, Iran (Lake Urmia, etc., the north coast of the Persian gulf, etc.), lakes of Southern Afghanistan (at an altitude of $3000 \mathrm{~m}$ ), up to Kazakhstan and western India (Fig. 2) has been estimated at 500,000 birds (Rose \& Scott, 1997; Andrusenko, 1980, 2007); in the late twentieth century, no serious changes in the abundance were observed (Johnson, 1997, 1998).

As a result of my bibliographic study, it was found that the northern part of the range of the Asian population of the greater flamingos includes the nesting sites, summerings, winterings and migration routes in the Caspian Sea region and along the Caspian Sea, in Central and Southern Kazakhstan, Turkmenistan, Azerbaijan and Russia. Before the early twenty-first century, the main nesting sites of flamingo were located in the Caspian Sea region and on the Caspian Sea.

Until 1930 there was a relative stability of the global climate conditions in Northern Eurasia, which determined the state of the water level in the Caspian Sea. During this period, the monitoring of flamingos in the northern part of the Asian population took the form of collecting mainly qualitative information, with determination of locations of breeding colonies, summerings and winterings; the abundance of flamingos was characterized mainly using epithets. 


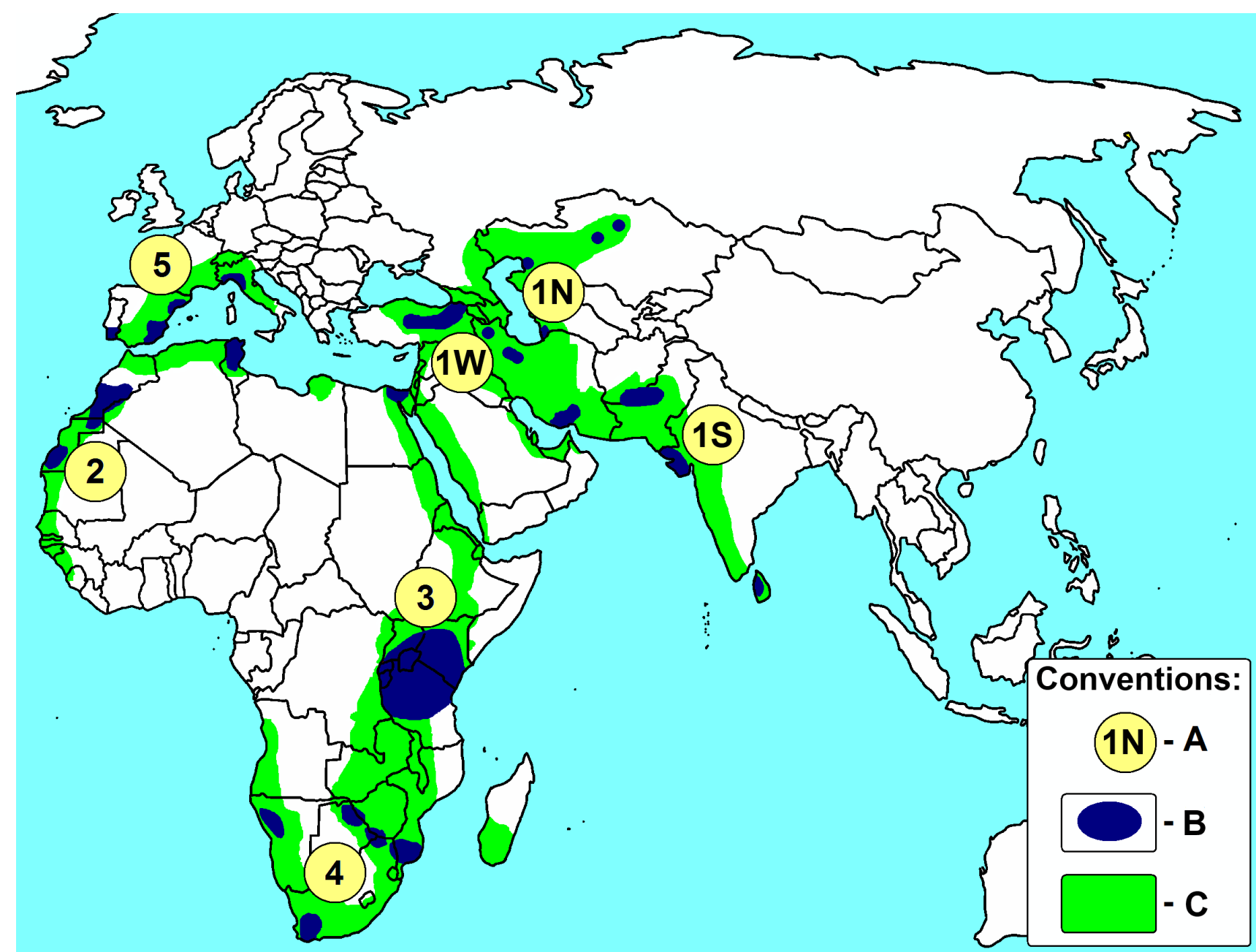

Fig. 2. The range of the greater flamingo in the Old World: A - breeding populations $[1$ - Asian (including: $1 \mathrm{~W}$ - western part; $1 \mathrm{~S}$ - south part; $1 \mathrm{~N}$ - northern part); 2 - West-African; 3 - East-African; 4 - South-African; 5 - Western Mediterranean, according to Johnson, 1997, 1998 with modifications]; $\mathrm{B}$ - nesting sites; $\mathrm{C}$ - nomadic sites.

The subsequent period of 1931-1977 was caused by the development of anthropogenic influences and changes in global climatic conditions in Northern Eurasia, which determined a decrease in the water level in the Caspian Sea. Ecological consequences of the change in the hydrological regime were the most significant in the shallow north-eastern part of the sea. Sites of nesting and summering located here have changed dislocation, sometimes in a considerable range, up to total loss. In this period, the observations of flamingos took the form of clarifying quantitative and qualitative information, with the determination of new locations of breeding colonies and the duration of their existence, sites of summerings and winterings, the size of flocks and groupings, the reasons for the disappearance of flamingos from the former habitats.

It was found that the appearance of permanent breeding colonies in Central Kazakhstan (on Lake Shalkarteniz, Lake Tengiz, etc.) was caused by the steady decline of the area of the Caspian Sea, drying up of several gulfs, whereby the breeding colonies of flamingos were gradually forced to move out from the seacoasts. That was also caused by the decrease of the level of continental waterbodies in Central Kazakhstan which resulted in an increase of their breeding and feeding properties: formed shallows became the feeding habitats and the place for nesting of flamingos. Significant annual and long-term fluctuations in the water level, which are inherent for semiarid waterbodies, have affected the presence or absence of sites suitable for building nests, as well as these factors affected the concentration of salts, which, in turn, influenced the composition and quantity of aquatic organisms - food items of the greater flamingo. All this was the reason for the periodic disappearance of the colonies of flamingos on some lakes and their emergence on other lakes having a more suitable hydrological regime. The instability of 
the ecological conditions during this period had contributed significantly to the formation of the northern part of the range of the Asian population within those borders that became habitual for researchers during the second half of the twentieth century.

During 1978-2015, the observations of flamingos in the northern part of the range of the Asian population were aimed to obtain qualitative and quantitative indicators of sites of nesting, wintering and summering in the conditions of increase of the Caspian Sea level and fluctuations in water availability of Central Kazakhstan, and clarification of time of migration, spring and autumn migration routes. The placement of the major part of flamingos on the waterbodies of Central Kazakhstan by the late XX century, contributed to the final formation of the migration route, which connected these habitats with areas that were previously populated at the Caspian Sea. In the early twenty-first century, the breeding colony on Lake Tengiz has remained the permanent reproductive centre in the northern part of the Asian population.

\section{Conclusions}

1. Over a period of 205 years (1811-2015), censuses of nesting sites and nesting birds, summerings and non-breeding birds, winterings and wintering birds were carried out by different authors at different times in different areas within the northern part of the range of the Asian population of the greater flamingo. This forms the necessary information base for further quantitative and qualitative assessment of the population during the whole period of its development.

2. There were found three time periods in the development of the northern part of the Asian population of flamingos. These were caused by the state of the Caspian Sea, the waterbodies of the Caspian region and Central Kazakhstan, each of which has specific characteristics that determines the placement of nesting colonies, summerings and winterings, as well as the seasonal and inter-seasonal migration routes in the northern part of the range and beyond.

\section{References}

Abdusalyamov I.A. 1971. The fauna of the Tajik SSR. Vol. 19, part 1: Birds. Dushanbe: Donish. 404 p. [In Russian]

Adamian M.S., Klem D.Jr. Handbook of the Birds of Armenia. Amer. Univ. of Armenia, Oakland, California. 1999. P. 1-649.
Andronov V.A., Ardamatskaya T.B., Artyukhin Yu.B. [et al.] 2011. Birds of Russia and adjacent areas. Vol. 7: Pelecaniformes, Ciconiiformes, Phoenicopteriformes. Moscow: KMK Scientific Press Ltd. 602 p. [In Russian]

Andrusenko N.N. 1979. The feeding possibilities and importance of waterbodies of the Kurgaldzhinskiy Reserve for waterfowl populations in Western and Central Siberia during their summer molting. In: $M i-$ gration and ecology of birds in Siberia. Yakutsk. P. 117-118. [In Russian]

Andrusenko N.N. 1980. Flamingo. Priroda 12: 72-75. [In Russian]

Andrusenko N.N. 1981. The population dynamics of colonial waterbirds during the breeding season on the lake Tengiz. In: The placement and state of the nesting sites of waterbirds in the USSR. Moscow: Nauka. P. 118-120. [In Russian]

Andrusenko N.N. 1986. The autumn migrations of the flamingo in the USSR. In: Migrations of birds in Asia. Novosibirsk. P. 150-158. [In Russian]

Andrusenko N.N. 2007. The greater flamingo. In: Birds of the Middle Asia. Almaty. P. 131-136. [In Russian]

Andrusenko N.N., Zhuliy V.A. 1977. About nesting and molting of flamingo on the lake Tengiz in 1976. In: VII All-Union Ornithological Conference. Part 2. Kiev: Naukova Dumka. P. 189-190. [In Russian]

Andrusenko N., Zhuliy V. 1978. The richness of the Kurgaldzhinskiy Reserve. Hunting and hunting economy 9: 2-4. [In Russian]

Ataev K., Vasiljev V.I., Gorelova R.I., Karavaev A.A., Kekilova A.F., Sopyev O., Eminov A. 1978. Materials about rare and endangered species of bird fauna of Turkmenistan. In: Proceedings of the Academy Sciences of the Turkmen SSR. Series of Biological Sciences 4: 70-80. [In Russian]

Auezov E.M. 1977. Materials about rare and endangered birds of lakes in the Tengiz-Kurgaldzhynskaya lowland and Turgay depression. In: Rare and endangered mammals and birds of Kazakhstan. Alma-Ata. P. 131-134. [In Russian]

Auezov E.M. 1991. Brief reports about flamingos (in Aktyubinsk region). In: Rare birds and mammals of Kazakhstan. Alma-Ata. 80 p. [In Russian]

Auezov E.M., Grachev V.A. 1977. Endangered and rare birds of the Alakol basin. In: Rare and endangered mammals and birds of Kazakhstan. Alma-Ata. P. 135-138. [In Russian]

Auezov E.M., Vinogradov V.G. 1986. Summer aerial survey of waterfowls on the waterbodies of the Turgay depression. In: Study of birds in the USSR, their protection and rational usage. Part 1. Leningrad. P. 46-47. [In Russian]

Azarov V.I., Zhiryakov V.A. 1976. Materials on the autumn migration of waterfowl and wading birds on lakes of the Kurgaldzhinskiy Reserve. In: Fauna and ecology of animals of the Tyumen region. Tymen. P. 80-94. [In Russian]

Babenko V. 2005. Kyzyl-Agach - bird refuge. Nauka i Zhizn' 7: 141-144. [In Russian] 
Balkiz O., Bechet A., Rouan L., Choquet R., Germain Ch., Amat J.A., Rendonmartos M., Baccetti N., Nissardi S., Ozesmi U., Pradel R. 2010. Experience dependent Natal Philopatry Of Breeding Greater Flamingos. Journal of Animal Ecology 79 (5): 1045-1056.

Bechet A., Johnson A.R. 2008. Anthropogenic and environmental determinants of Greater Flamingo Phoenicopterus roseus breeding numbers and productivity in the Camargue (Rhone delta, southern France). Ibis 150 (1): 69-79.

Berezovikov N.N. 2001. About the cases of deaths of flamingos Phoenicopterus roseus during autumn migrations in Kazakhstan. Russian ornithological journal 136: 226-227. [In Russian]

Berezovikov N.N. 2012. Materials for avifauna of the delta of Syrdarja river and the Maloe Aral Sea. Russian ornithological journal 21: 1619-1653. [In Russian]

Berezovikov N.N., Anisimov E.I. 2002. The cases of occasional flown of flamingos in Alakol basin. Kazakh Ornithological Bulletin. P. 56. [In Russian]

Berezovikov N.N., Gistsov A.P. 1996/1997. Ornitological complexes of the delta of the Ural river and their change due to the next transgression of the Caspian Sea. Selevinia 2: 79-87. [In Russian]

Berezovikov N.N., Levinskiy Yu.P. 2005. Ornitological observations in the Alakol basin in 2004. Kazakh Ornithological Bulletin. P. 72-79. [In Russian]

Berezovikov N.N., Levinskiy Yu.P. 2009. New observation of flamingo Phoenicopterus roseus on the lake Alakol. Russian ornithological journal 18: 828. [In Russian]

Berezovikov N.N., Koshkin A.V. Gavrilov A.E., Kovalenko A.V. 2014. Staty of avifauna of the Tengiz-Kurgaldzhyn system of lakes during period of shallowing and drying up of waterbodies in 2012. Russian ornithological journal 23: 2191-2200. [In Russian]

Berezovsky V.G. 1983. Spring migration of waterfowls on the east coast of the Aral Sea in 1978-1979. In: Migration of birds in Asia. Alma-Ata. P. 26-34. [In Russian]

Bianki V.L. 1902. Materials for avifauna of the Akmolinskiy region (presented at 20 October, 1901). Yearbook of the Zoological Museum of the Imperial Academy of Sciences 7: 10-30. [In Russian]

Bostanzhoglo V.N. 1911. Ornithological fauna of the AralCaspian steppes. Materials to the knowledge of the fauna and flora of the Russian Empire. Department of Zoology. Vol. 11. 410 p. [In Russian]

Bragin E.A., Bragina T.M. 2002. Fauna of the Naurzum Reserve (Osteichthyes, Amphibia, Reptilia, Aves, Mammalia). Kostanay: Kostanay Publishing House. 60 p. [In Russian]

Bukreev S.A. 1997. Ornithology and preservation in Turkmenistan. Moscow: SCWL SEU. 156 p. [In Russian]

Butjev V.T., Mikheev A.V., Kostin A.B. [et al.]. 1989. Notes on the rare species of the Caucasian coast of the Caspian Sea birds (estuary of the Samur river, Dagestan ASSR). In: Ornithological resources of the North Caucasus. Stavropol. P. 137-152. [In Russian]
Buturlin S.A. 1936. Vagrant flamingos. Hunter of Siberia 5: 23. [In Russian]

Carri-Lindal K. 1984. Birds above the land and sea: global overview of bird migrations. Moscow: Mysl. 204 p. [In Russian]

Cezilly F., Johnson A.R. 1995. Re-mating between and within breeding seasons in the Greater Flamingo Phoenicopterus ruber roseus. Ibis 137 (4): 543-546.

Chekmenev D.I. 1962. Distribution and abundance of colonial birds on the lake Tengiz (Central Kazakhstan). In: Materials of III All-Union Ornithological Conference. Book 2. Lviv. P. 22-33. [In Russian]

Chekmenev D.I. 1964. Feature articles on the biology of colonially nesting birds of the Tengiz lake. In: Proceedings of the Institute of Zoology of the Academy of Sciences of the Kazakh SSR 24: 70-76. [In Russian]

Cheltsov-Bebutov A.M. 1958. New nesting site of flamingo in the Soviet Union. Ornithology 197: 95101. [In Russian]

Chernobay V.F. 2004. Birds of the Volgograd region. Volgograd: Publishing House of the Volgograd State Pedagogical University; «Peremena». 287 p. [In Russian]

Chernoskutov I.A., Badamishin B.I. 1948. The large cluster of flamingo in the Caspian Sea. Priroda 4: 83. [In Russian]

Chernov V.Yu. 1990. The large cluster of flamingo Phoenicopterus ruber in the Caspian Sea. Environmental issues. Inventory of natural resources of the Chardzhou region 1: 103-118. [In Russian]

Danilenko E.A. Danilenko A.K., Chibisova V.V. 1977. On the distribution of flamingos in post-nesting period. Ornithology 13: 202-204. [In Russian]

Dementjev G.P. 1945. On the fauna of terrestrial vertebrates of southwestern Turkmenistan. Scientific notes of the Moscow State University named after Lomonosov 83: 65-66. [In Russian]

Dementjev G.P. 1952. Birds of Turkmenistan. Ashkhabad. 547 p. [In Russian]

Dementjev G.P., Meklenburtsev R.N., Sudilovskaya A.M., Spangenberg E.P. 1951. Birds of the Soviet Union. Vol. 2: Order flamingo. Moscow: Sovetskaya nauka. P. 221227. [In Russian]

Dinesman I.A. 1960. Changes in the nature of the north-west of the Caspian lowland. Moscow. 160 p. [In Russian]

Dolgushin I.A. 1960. About flamingos on the lake Tengiz (Central Kazakhstan). Proceedings of the Institute of Zoology of the Academy of Sciences of the Kazakh SSR 13: 67-95. [In Russian]

Dolgushin I.A. 1960. Order flamingo. In: Birds of Kazakhstan. Vol. 1. Alma-Ata: Nauka. P. 224-237. [In Russian]

Dyakin G.Yu. 1991. Brief reports about flamingos (in Mangyshlak region). In: Rare birds and mammals of Kazakhstan. Alma-Ata. P. 80. [In Russian]

Dyunin A.G. 1960. Change of the composition of the avifauna of the Maly Kyzyl-Agach gulf due to its desalination. Protection of nature and gardening 4: 46-52. [In Russian]

Dzhamirzoev G.S. 2009. The greater flamingo. In: Red Data Book of the Republic of Dagestan. Makhachkala. P. 419-420. [In Russian] 
Eichwald E. 1837. Reise auf dem Caspischen Meer und in dem Caucasus. Bd. 1.21 S. [In German]

Elkin K.F. 1969. About the flamingo in Central Kazakhstan. In: Ornithology in the USSR. Book 2. Ashkhabat. P. 42-44. [In Russian]

Elkin K.F., Volkov E.N., Zhuliy V.A. 1975. Water availability of lakes and state of avifauna in the Northern and Central Kazakhstan. Problems of Geography of Kazakhstan 17: 44-55. [In Russian]

Erokhov S.N., Berezovikov N.N. 2009. Materials to the avifauna of the lake steppe and forest-steppe in the Kustanay region. Part 1. Russian ornithological journal 18: 1715-1742. [In Russian]

Eversmann E.A. 1866. The natural history of birds in the Orenburg Region. In: Natural history of the Orenburg region. Kazan. Vol. 3. P. 621. [In Russian]

Eversmann E.A. 1885. Flamingos. Nature and hunting 1: 69. [In Russian]

Garbuzov V. 2000. Flamingo on the lake Chelkar-Tengiz. Nauka i Zhizn' 10: 42-45. [In Russian]

Gavrin V.F. 1968. Hunting waterfowls of the TengizKurgaldzhyn system of lake. In: Resources of waterfowls in the USSR, their reproduction and usage. Part II. The Asian part of the USSR. Moscow. P. 25-27. [In Russian]

Gistsov A.P. 1994. Flamingo in the North-East Caspian. Selevinia 2 (3): 89-92. [In Russian]

Gistsov A.P. 2001. Rare birds of the north-eastern coast of the Caspian Sea. In: Actual problems of study and protection of birds of Eastern Europe and Northern Asia. Kazan. P. 176-178. [In Russian]

Gistsov A.P. 2004. Monitoring the status of waterfowls in Northern Caspian on boundary of the twentieth and twenty-first centuries. In: Proceedings of the Institute of Zoology of the Ministry of Education and Science of the Republic of Kazakhstan. Ornithology 48: 260-278. [In Russian]

Gistsov A.P., Gavrilov E.I., Borodikhin I.F. 1977. Supplement to the avifauna of the Western Tien Shan. In: $M i-$ grations of birds in Asia. Novosibirsk. P. 215-218. [In Russian]

Grekov V.S. 1962. About wintering of flamingo in the KyzylAgachsky Reserve. Ornithology 5: 356-362. [In Russian]

Gubin B.M. Gavrilov E.I., Khrokov V.V. 1977. Ornitological records in the lower reaches of the Ural river. In: Migrations of birds in Asia. Novosibirsk. P. 209-211. [In Russian]

Ignatov P.G. 1900. Tengis-Kurgaldzhyn lake basin in Akmolinsk region. Proceedings of the Russian Geographical Society 36 (4): 26. [In Russian]

Ioganzen G.E. 1911. Strayed flamingo (Phoenicopterus roseus) in Siberia in early of winter 1907. Ornithological Vestnik 3/4: 332-342. [In Russian]

Isakov Yu.A. 1948a. Notes on the biology of flamingos. In: Caspian gull and flamingo in the Caspian Sea. Moscow: General Administration of Reserves of the RSFSR. P. 45-54. [In Russian]

Isakov Yu.A. 1948b. Towards the distribution of flamingos in the USSR. In: Caspian gull and flamingo in the Caspian
Sea. Moscow: General Administration of Reserves of the RSFSR. P. 55-60. [In Russian]

Isakov Yu.A. 1949. Current state of wintering of waterfowl on the western shore of the Caspian Sea. Proceedings of the Central Bureau of birdbanding 7: 16-22. [In Russian]

Isakov Yu.A., Vorobjev K.A. 1940. Overview of winterings and migrations of birds in the South Caspiam region. Proceedings of the Caspian Reserve Hasan Kuli 1: 5-159. [In Russian]

IUCN Red List of Treatened Species. Moscow, 2012. 210 p. [In Russian]

Johnson A.R. 1997. Long-term studies and conservation of greater flamingos in the Camargue and the Mediterranean. Colonial Waterbirds 20: 306-315.

Johnson A.R. 1998. Some noteworthy recoveries. Flamingo Specialist Group Newsletter 8: 21.

Johnson A., Cezilly F., Boy V. 1992. Plumage development and maturation in the greater flamingo (Phoenicopterus ruber roseus). Ardea 81: 25-34.

Karavaev A.A. Belousov E.M. 1983. Migration of birds in the South-East Caspian region in autumn 1977. In: $M i-$ gration of birds in Asia 8: 52-65. [In Russian]

Karelin G.S. 1875. Analysis of the article of A. Ryabinin «Natural works of lands of the Ural Cossack troops». Proceedings of the St. Petersburg Society of Naturalists 6: 22. [In Russian]

Karelin G.S. 1883. Traveling along the Caspian Sea. In: Notes of the Imperial Russian Geographical Society on general geography. Vol. 10. St. Petersburg. 188 p. [In Russian]

Kassal B.Yu. 2010. Phoenicopteriformes. In: Encyclopedia of the Omsk region. Vol. 2. Omsk: Omsk Book Publisher. P. 478. [In Russian]

Kassal B.Yu. 2015. The greater flamingo Phoenicopterus roseus. In: G.N. Sidorov, N.V. Plikina (eds.): Red Data Book of the Omsk region. Omsk: Publishing House of the Omsk State Pedagogical University. P. 170-171. [In Russian]

Kazakov B.A., Lomadze N.Kh., Belik V.P. [et al.]. 2004. Birds of the Northern Caucasus. Volume 1: Gaviiformes, Podicipediformes, Procellariiformes, Copepods, Ciconiiformes, Phoenicopteriformes, Anseriformes. Rostovon-Don. 398 p. [In Russian]

Khlebnikov V.A. 1930. Birds of the Astrakhan region. In: Yearbook of the Astrakhan regional museum. Museum catalog. Zoological Department. Birds. Astrakhan. 31 p. [In Russian]

Khokhlov A.N. 1988. Flamingo in the Ciscaucasia. In: Resources of rare animals of the RSFSR, their protection and reproduction (Proceedings of the Red Data Book). Moscow: Central Research Laboratory. P. 65-67. [In Russian]

Khrokov V.V. 1991. Brief reports about flamingos (in the Alma-Ata region). In: Rare birds and mammals of $\mathrm{Ka}$ zakhstan. Alma-Ata. P. 81. [In Russian]

Khrokov V.V. 2010. Observations of birds in the Central and South-East Kazakhstan in May 2010. Russian ornithological journal 19: 1580. [In Russian] 
Khrokov V.V., Koshelev A.I. 1989. Birds of lakes and marshes. Alma-Ata: Kaynar. P. 82-84. [In Russian]

Klimov A.S. 1991. Brief reports about flamingos (in Guryev region). In: Rare birds and mammals of Kazakhstan. Alma-Ata. P. 79. [In Russian]

Kolmagorov M. 1925. To the observations of flamingo in the neighborhoods of the city of Ust-Kamenogorsk. Hunter of Altai 3: 3. [In Russian]

Komarova N.A., Komarov Yu.E. 1988. About wintering of waterbirds on the Ossetian plain. In: Wildlife resources of the North Caucasus. Stavropol. P. 90-93. [In Russian]

Koshkin A.V. 2004. On the reduction of several species of birds in 2004 on the territory of Tengiz district (Central Kazakhstan). Selevinia. P. 226-227. [In Russian]

Kostin V.P. 1956. Notes on the avifauna of left bank of the lower reaches of the Amudarja and Ustyurt. Proceedings of the Institute of Zoology and Parasitology 8: 81-127. [In Russian]

Krasovsky D.B. 1932. Materials to the knowledge of the fauna of terrestrial vertebrates of the Rutul canton DASSR. Proceedings of the second North Caucasian Pedagogical Institute 9: 186-219. [In Russian]

Kreytsberg E.A. 2008. Lake Sudochje. In: Important Ornithological Areas in Uzbekistan. Tashkent. P. 68-71. [In Russian]

Krivenko V.G. 1991. Waterfowls (Sredinnyi region) and their protection. Moscow: Agropromizdat. 271 p. [In Russian]

Krivitskiy I.A., Khrokov V.V., Volkov E.N., Zhuliy V.A. 1985. Birds of the Kurgaldzhinskiy Reserve. Alma-Ata. 194 p. [In Russian]

Krivonosov G.A., Morozkin N.N., Skokova N. 1978. Problems of the Kyzyl-Agach (to save important wintering of birds). Hunting and hunting economy 11: 14-16. [In Russian]

Krivonosov G.A., Rusanov G.M., Anisimov E.I. 1984. The abundance and placement of waterfowls in coastal shallow waters of the north and north-east of the Caspian Sea in 1983. The current state of resources of waterfowl. Moscow. P. 88-91. [In Russian]

Kustanovich S.D. 1986. Fire-bird of the Red Data Book (Greater flamingo). Moscow: Nauka. P. 80. [In Russian]

Kuznetsov N.T. 1960. Fluctuation of water levels in lakes of Northern Kazakhstan. In: Lakes of Northern Kazakhstan. Alma-Ata. P. 57-79. [In Russian]

Lankin P. 1981. Flamingo in Eastern Caspian region. Hunting and hunting economy 12: 14-15. [In Russian]

Laptev M.K. Sulima V.I., Freyberg L.R. 1934. All-Union ornithological reserve in Gasan-Kuli of the Turkmen SSR. Proceedings of Turkmen Interdepartmental Commission for the protection of nature and development of natural resources. Biology Series 1: 41-114. [In Russian]

Lavrov S.D. 1930. Results of zoological expedition to the Tengiz-Kurgaldzhyn lake basin. The route of the Tengiz-Kurgaldzhyn expeditions and the nature of visited region. Proceedings of the West-Siberian Geographical Society 7: 133-157. [In Russian]
Lebedeva M., Shevareva T. 1971. About occasional observations of flamingos. Hunting and hunting economy 7 : 18-19. [In Russian]

Litvinova N.A., Tkachenko E.E., Litvinov V.P. 1984. Nesting of flamingo in the Kyzyl-Agachsky Reserve. Ornithology 19: 182-183. [In Russian]

Lugovoy A.E. 1963. Birds of the delta of the Volga river. Proceedings of the Astrakhan Nature Reserve 8: 9-185. [In Russian]

Luri V.N., Sabinevskiy B.V. 1968. The state of East-Caspian winterings of waterfowls in January 1968. In: Resources of waterfowls in the USSR, their reproduction and usage. Part II. The Asian part of the USSR. Moscow. P. 3-4. [In Russian]

Meklenburtsev R.N. 1987. Order Phoenicopteriformes. In: Birds of Uzbekistan. Vol. 1. Tashkent. P. 55-56. [In Russian]

Menzbir M.A. 1918. Birds of Russia (European Russia, Siberia, Turkestan, Trans-Caspian region and Caucasus). Issue 1. Moscow: Publishing House of M.S. and S. Sabashnikov. 224 p. [In Russian]

Mikheev A.V. 1997. Visible daytime migration of the waterfowl and wading birds on the western coast of the Caspian Sea. Stavropol. 156 p. [In Russian]

Mikheev A.V. 1985. Daytime migration of birds along the western coast of the Caspian Sea. In: Birds of the Northwest Caucasus. Moscow. P. 5-19. [In Russian]

Molodovsky A.V. 1963. Flamingos in the South Mangyshlak. Zoologichesky Journal 42 (12): 22-33. [In Russian]

Morozkin N.I. 1975. Migration and wintering of waterfowls in the Kyzyl-Agachsky Reserve in 1971-1974. In: Proceedings of the I All-Union Conference on bird migration. Part I. Moscow: Publisher of the Moscow State University. P. 12-18. [In Russian]

Nasarow P.S. 1887. Journey through the Kirghiz steppe. Blackwood's Edinburgh Magazine OXXXVIII: 177-195.

Nazarenko E.A., Bessonov S.A. 2009. Greater flamingo. In: Vertebrates of Russia. Available at: www. sevin.ru/vertebrates/pre birds.html (Accessed on 02.02,2016). [In Russian]

Neruchev V.V. 1991. Brief reports about flamingos (in the Gurjev region). In: Rare birds and animals of Kazakhstan. Alma-Ata. P. 79. [In Russian]

Neruchev V.V., Khudyakov I.V. 1967. New data on the flamingos on the north-east coast of the Caspian Sea. Ornithology. 8: 22-33. [In Russian]

Neyfeld I.A. 1967. New data on the flamingos on the northeast coast of the Caspian Sea. Ornithology 8: 375-376. [In Russian]

Nikolskiy A.M. 1886. Trip to the north-eastern Persia and the Transcaspian region. Notes of the Russian Geographical Society about general geography 15: 57. [In Russian]

Oliger I.M. 1955. Summary determinant of vertebrates. Moscow. 142 p. [In Russian]

Orlov V.I. 1967. About wintering of birds on the Turkmen coast of the Caspian Sea. In: Proceedings of the III Conference of the RSFSR zoological pedagogical institutions. Volgograd. P. 441-443. [In Russian]

Pallas P.-S. 1811. Zoogeographia Rosso-Asiatica. St.Petersburg. 420 p. [In Latin] 
Patrikeev M. 2004. Birds of Azerbaijan. In: Series Faunistica. №38. Pensoft Publishers. 380 p. [In Russian]

Pishvanov Yu.V., Prilutskaya L.I. 1988. Brief data about the rare species of birds of Dagestan. In: Resources of rare animals in the USSR, their protection and reproduction. Moscow. P. 88-92. [In Russian]

Plotnikov V.N. 1912. New and vagrant mammals and birds in neighborhoods of the Yamishevskiy village in the Pavlodar county of Semipalatinsk region. Notes of Semipalatinsk subsection of the West-Siberian Branch of the Russian Geographic Society 6: 1-4. [In Russian]

Polyakov G.I. 1915. Ornithological surveys of A.P. Velizhanin in the Upper Irtysh basin. Ornithological Vestnik. Appendix №3. P. 1-32, 33-64. [In Russian]

Poslavskiy A.N. Sabinevskiy B.V., Luri V.N. 1977. Flamingo Phoenicopterus roseus in the Northeast Caspian region. In: Rare and endangered mammals and birds of $\mathrm{Ka}$ zakhstan. Alma-Ata. P. 143-146. [In Russian]

Prisyazhnyuk V.E. 2012. Red List of protected, rare and endangered plant and animal species. Issue 3. Part 1. Vertebrates. (Bulletin of the Red Data Book 5/2012). Moscow: Laboratory of the Red Data Book of the AllRussian Research Institute for Nature Conservation. 448 p. [In Russian]

Radde G.I. 1885. Ornithological fauna of the Caucasus. Tiflis. 451 p. [In Russian]

Radde G., Walter A. 1889. Die Vogel Transcaspiens. Ornis 5: 1-128, 165-279. [In German]

Red Data Book of Altai Krai. Vol. 2. Animals. Rare and endangered animal species. Barnaul: «Altay», 2006. 211 p. [In Russian]

Red Data Book of Azerbaijan SSR. Rare and endangered species of animals and plants. Baku: Ishyg, 1989. 543 p. [In Russian]

Red Data Book of Kazakh SSR. Rare and endangered species of animals and plants. Vol. 1. Animals. Part 1: Vertebral. Almaty, 1978. 205 p. [In Russian]

Red Data Book of Russian Federation (Animals). Moscow: Astrel, 2001. 860 p. [In Russian]

Red Data Book of the Republic of Kazakhstan. Vol. 1. Animals. Part 1: Vertebral. Almaty, 2010. 324 p. [In Russian]

Red Data Book of the Republic of Uzbekistan. Vol. 2. Animals. Tashkent, «ChinorEnk», 2006. 216 p. [In Russian]

Red Data Book of the Turkmen SSR. Vol. 1: Rare and endangered species of animals and plants. Ashgabat: Turkmenistan, 1985. P. 158-161. [In Russian]

Red Data Book of the USSR. Rare and endangered species of animals and plants. Vol. 1. Moscow: Lesnaya promyshlennost, 1984. 466 p. [In Russian]

Red Data Book of Turkmenistan. Vol. 1: invertebrates and vertebrates. Birds. Ashkhabad: Turkmenistan, 1999. P. 202-290. [In Russian]

Reutskiy N.D. 2014. The greater flamingo. An annotated list of birds of the Astrakhan region, with indicating their distribution through natural territorial complexes (part three). Astrakhan Gazette Environmental Education 3 (29): 99-101. [In Russian]
Rose P.M., Scott D.A. 1997. Waterfowl population estimates. In: Wetlands International. Wageningen, Netherlands. P. 22-33.

Rusanov G.M. 2002. Birds in the delta of the Volga river and adjacent areas. Astrakhan. 68 p. [In Russian]

Rusanov G.M. 2004. One autumn I got a call from familiar fisherman. Zeleny Mir№9/10: 15. [In Russian]

Rusanov G.M., Krivonosov G.A. 1988. Flamingo (Phoenicopterus roseus Pall.) in the North and Northeast Caspian Sea in conditions of the modern increasing of the sea level. Bulletin of Moscow Society of Naturalists, Department of Biology 93 (3): 13. [In Russian]

Rusanov G.M., Krivonosov G.A., Anisimov E.I. 1991. The abundance and placement of flamingos near the northern and north-eastern coast of the Caspian Sea. In: Rare birds and mammals of Kazakhstan. Alma-Ata. P. 76-78. [In Russian]

Salama W., Grieve A. 1996. The Zaranik experience. Sandgrouse 18: 14-17.

Samarin E.G., Saraev F.A., Bidashko F.G. 1991. Brief reports about flamingos (in the Gurjev region). In: Rare birds and mammals of Kazakhstan. Alma-Ata. P. 79. [In Russian]

Samraoui B., Ouldjaoui A., Boulkhssaïm M., Houhamdi M., Saheb M., Béchet A. 2006. The first recorded reproduction of the Greater Flamingo Phoenicopterus roseusin Algeria: behavioural and ecological aspects. Journal Ostrich 77 (3-4): 153-159.

Satunin K.A. 1907. Materials towards the knowledge of birds in the Caucasus region. Tbilisi: Publishing K.P. Kozlowski. 130 p. [In Russian]

Seebohm N. 1882. Notes on the birds of Astrachan. Ibis 6 (2): 54 .

Selevin V.A. 1924. Towards the cases of occasional flown of flamingos to the Ust-Kamenogorsk. Hunter of Altai 8 (2): 20-21. [In Russian]

Selevin V.A. 1927. The cases of occasional flown of flamingo Phoenicopterus ruber in the Semipalatinsk province. Uragus 4 (9): 9-13. [In Russian]

Severtsev N.A. 1879. Notes on the vertebrate fauna of the Pamir. Notes of the Turkestan branch of the Society of Naturalists, Anthropology and Ethnography 1 (1): 5889. [In Russian]

Shcherbakov B.V. 1991. Brief reports about flamingos (in the East-Kazakhstan region). In: Rare birds and mammals of Kazakhstan. Alma-Ata. P. 81. [In Russian]

Shcherbakov B.V. 1999. Ornithological news of Eastern Kazakhstan. In: Problems of conservation and sustainable usage of fauna biodiversity of Kazakhstan. Almaty. P. 93-94. [In Russian]

Sludskiy A.A. 1959. On the nesting sites of flamingos. In: Hunting and hunting economy 3: 24. [In Russian]

Sludskiy A.A. 1960. Flamingo in the Soviet Union and objectives of its protection. In: Birds of the waterbodies (Nature conservation and gardening). Issue 4. Moscow: All-Russian Society for Nature Protection. P. 95-98. [In Russian]

Solomatin S.A. 1991. Brief reports about flamingos (in the Pavlodar region). In: Rare birds and mammals of $\mathrm{Ka}$ zakhstan. Alma-Ata. P. 80. [In Russian] 
Spangenberg E.P. 1951. Order flamingo, In: Birds of the Sovie Union. Vol. 2. Moscow: Sovetskaya Nauka. P. 341349. [In Russian]

Starikov S.V., Vorobjev V.M. 2011. Vagrant flamingo Phoenicopterus ruber on the Southern Altai. Russian ornithological journal 20: 2442-2443. [In Russian]

Stepanyan L.S. 2003. Summary of the ornithological fauna of Russia and adjacent territories. Moscow: «Akademkniga». 806 p. [In Russian]

Stotskaya E.I., Krivenko V.G. 1988. Rare species according to the materials All-Union censuse of colonial nesting sites of waterbirds and seabirds. In: Resources RSFSR rare animals, their protection and reproduction. Moscow. P. 39-46. [In Russian]

Sushkin P.P. 1898. The second trip to the Central Kirghiz steppe for ornithological and lepidopterological studies. Manuscript. [In Russian]

Sushkin P.P. 1908. Birds of the Central Kirghiz steppe (Turgay region and the eastern part of the Ural region). In: Materials to the knowledge of the fauna and flora of the Russian Empire. Department of Zoology. Issue 8. Moscow. 120 p. [In Russian]

Sushkin P.P. 1914. Notes on the Caucasian birds. Ornithological vestnik 1: 1-44. [In Russian]

Sushkin P.P. 1925. List and distribution of birds in the Russian Altai and adjacent areas of the North-Western Mongolia with the description of new or little-known forms. Leningrad, P. 1-79. [In Russian]

Syroechkovskiy E.E., Rogacheva E.V. 1975. The fauna of the USSR (Geography of resources). Moscow: Mysl. 439 p. [In Russian]

Ten A.G., Atakhodzhaev A.A., Sudarev V.O. 2009. Greater flamingo. Species composition, abundance and distribution of rare bird species in the Southern Aral Sea region in summer 2009. Report on field research in the Southern Aral Sea region in the summer of 2009. Tashkent. 32 p. [In Russian]

Touatiab L., Samraoui B. 2013. Diversity and distribution of avian lice on Greater Flamingo chicks (Phoenicopterus roseus) in Algeria. Avian biology research 6 (4): 261-268.

Tugarinov A.Ya. 1909. Flamingo in Siberia. Nasha okhota 6: 77-80. [In Russian]

Tugarinov A.Ya., Kozlova-Pushkareva E.V. 1935. The wintering of birds on the Talysh. In: Proceedings of the Azerbaijan branch of the USSR Academy of Sciences. Zoological series. Vol. 33. Moscow; Leningrad. 126 p. [In Russian]

Tugarinov A.Ya., Kozlova-Pushkareva E.V. 1938. Life of birds during the wintering in the Kyzyl-Agachsky Reserve after S.M. Kirov. Proceedings of the Azerbaijan branch of the USSR Academy of Sciences. Zoological series 36: 110. [In Russian]

Varshavskiy S.N., Varshavskiy B.S., Gabuzov V.K. 1977. Some rare and endangered birds of the North Aral Sea region. In: Rare and endangered mammals and birds of Kazakhstan. Alma-Ata. P. 146-153. [In Russian]

Vasiljev V.I. 1976a. Materials to the seasonal placement, abundance and ecology of flamingo in the East Caspian.
In: Materials of meeting on commercial ornithology. P. 25-29. [In Russian]

Vasiljev V.I. 1976b. Migration and placement of waterfowl and wading birds on the Eastern Caspian wintering. In: Materials of meeting on commercial ornithology. P. 18-24. [In Russian]

Vilkov V.S. 2010. The avifauna of North Kazakhstan region. Russian ornithological journal 19: 947-967. [In Russian]

Vladimirskaya M.I., Mezhenny A.A. 1952. Avifauna of the lake Kurgaldzhin (North Kazakhstan). Proceedings of works on vertebrates, in memory of V.L. Bianki: Proceedings of the Zoological Institute of the USSR Academy of Sciences 9 (4): 44-52. [In Russian]

Volchanetskiy I.B. 1937. Towards the avifauna of the VolgaUral steppe. In: Proceedings of the Research zoological-biological institute. Environment sector. Vol. 4. Kharkov. P. 23-78. [In Russian]

Volkov E.N. 1972. The nesting of flamingo in Central Kazakhstan. Resources of the USSR waterfowls, their reproduction and usege. Book 2. Moscow. P. 22-33. [In Russian]

Volkov E.N. 1975. Changes in the number and placement of colonial birds on the lake Tengiz (Central Kazakhstan). In: The colonial nestings of waterbirds and their protection. Moscow. P. 125-129. [In Russian]

Volkov E.N. 1977a. About the location and abundance of central kazakh population of flamingo. In: Rare and endangered mammals and birds of Kazakhstan. Almaty. P. 153-167. [In Russian]

Volkov E.N. 1977b. On the range of flamingos during winter. In: VII All-Union Ornithological Conference. Part 2. Kiev: Naukova Dumka. P. 201-202. [In Russian]

Volkov E.N. 1979. Migrations of flamingo Phoenicopterus roseus Pall. In: Migrations of waterfowls in Eastern Europe and North Asia. Moscow: Nauka. P. 31-37. [In Russian]

Voronov A.G. 1947. About fluctuations of the level of lakes in the Kustanay region of the Northern Kazakhstan. Proceedings of the Russian Geographical Society 79 (5): 523-536. [In Russian]

Wakhsman A. 1982. Sea comes. Pravda. Issue 22 March: 4. [In Russian]

Yakovlev V.E. 1873. List of birds observed in the Astrakhan province. Bulletin Soc. Nat. Moscou 45 (2): 323-361. [In Russian]

Zaletaev V.S. 1960. New data on the distribution of flamingos in Western Turkmenistan. Birds of the waterbodies (Nature conservation and gardening). Issue 4. Moscow: All-Russia Society for Nature Conservation. P. 99-101. [In Russian]

Zarudny N.A. 1896. Ornithological fauna of the Transcaspian Krai (Northern Persia, Transcaspian region, Khininsk oasis of plain Bukhara). In: Materials to the knowledge of the fauna and flora Russian Empire. Department of Zoology 2: 555 p. [In Russian] 


\title{
ЗООГЕОГРАФИЧЕСКИЕ РЕЗУЛЬТАТЫ ДВУХВЕКОВОГО ИЗУЧЕНИЯ СЕВЕРНОЙ ЧАСТИ АЗИАТСКОЙ ПОПУЛЯЦИИ ФЛАМИНГО РОЗОВОГО
}

\author{
Б. Ю. Кассал \\ Омский государственный университет имени Ф.М. Достоевского, Россия \\ e-mail:BY.Kassal@mail.ru
}

За период в 205 лет были проведены десятки учетов гнездовий и гнездящихся особей, летовок и негнездящихся особей, зимовок и зимующих особей, выявления путей миграций в Прикаспии и на Каспийском море, в Центральном и Южном Казахстане, в Туркмении, Азербайджане и России. До начала XXI в. основные места гнездования фламинго располагались в Прикаспии и на Каспийском море в пределах Российской империи / СССР / стран СНГ. Установлено, что временной период до 1930 г. был обусловлен относительной стабильностью глобальных климатических условий в Северной Евразии, которые определили стояние уровня воды в Каспийском море. В этот период наблюдения за фламинго в северной части азиатской популяции носили характер сбора преимущественно качественной информации: установления мест размещения гнездовых колоний, летовок и зимовок; их численность характеризовалась в основном эпитетами. Следующий период 1931-1977 гг. был обусловлен развитием антропогенных влияний и изменением глобальных климатических условий в Северной Евразии, которые определили снижение уровня воды в Каспийском море. В мелководной северо-восточной части моря экологические последствия изменения гидрологического режима были наиболее значительны. Находившиеся здесь участки гнездования и летовок меняли дислокацию, иногда в значительных пределах, вплоть до полной утраты. В этот период наблюдения носили характер сбора количественной и уточнения качественной информации: установления новых мест размещения гнездовых колоний и длительности их существования, мест летовок и зимовок, размеров стай и группировок, причин исчезновения фламинго из прежних мест обитания. Появлению постоянных гнездовых колоний на озерах Центрального Казахстана (Шалкартенизе, Тенгизе и др.) способствовало неуклонное сокращение площади Каспийского моря, пересыхание ряда морских заливов. Снижение уровня континентальных водоемов в Центральном Казахстане повлекло усиление их гнездовых и кормовых свойств: образовавшиеся мелководья стали кормовыми стациями и местом устройства гнезд фламинго. Значительные годовые и многолетние колебания уровня воды в озерах стали причиной периодического исчезновения колоний фламинго на одних озёрах и появлению их на других. В период 1978-2015 гг. наблюдения за фламинго в северной части ареала азиатской популяции были направлены на получение качественных и количественных показателей мест гнездования, летовок и зимовок в условиях повышения уровня Каспийского моря и колебаний водности территории Центрального Казахстана, уточнения сроков миграций, весенних и осенних миграционных путей. Размещение к концу XX в. большей части фламинго на водоемах Центрального Казахстана способствовало окончательному формированию пролетного пути, соединившего эти местообитания с ранее населенными участками на Каспийском море. В начале XXI в. постоянным репродуктивным центром в северной части азиатской популяции фламинго розового оставалась гнездовая колония на оз. Тенгиз. Имеющиеся данные сформировали необходимую информационную базу для последующей количественной и качественной оценки северной части азиатской популяции за три временных периода, обусловленных состоянием Каспийского моря, водоемов Прикаспия и Центрального Казахстана, каждый из которых имел определенную характеристику, определявшую размещение гнездовых колоний, летовок, зимовок, пути сезонных и межсезонных миграций в северной части ареала фламинго и за его пределами.

Ключевые слова: Phoenicopterus roseus, азиатская популяция, гнездовая колония, зимовка, летовка, пути миграции, северная часть ареала, фламинго розовый, численность. 